\title{
Closing the peroxy acetyl nitrate budget: observations of acyl peroxy nitrates (PAN, PPN, and MPAN) during BEARPEX 2007
}

\author{
B. W. LaFranchi ${ }^{1}$, G. M. Wolfe ${ }^{2}$, J. A. Thornton ${ }^{3}$, S. A. Harrold ${ }^{3}$, E. C. Browne ${ }^{1}$, K. E. Min ${ }^{4}$, P. J. Wooldridge ${ }^{1}$, \\ J. B. Gilman ${ }^{5}$, W. C. Kuster ${ }^{5}$, P. D. Goldan ${ }^{5}$, J. A. de Gouw ${ }^{5}$, M. McKay ${ }^{6, *}$, A. H. Goldstein ${ }^{6}$, X. Ren ${ }^{7, * *}$, J. Mao ${ }^{7, * * *}$, \\ and R. C. Cohen ${ }^{1,4}$ \\ ${ }^{1}$ Department of Chemistry, University of California, Berkeley, Berkeley, CA, USA \\ ${ }^{2}$ Department of Chemistry, University of Washington, Seattle, WA, USA \\ ${ }^{3}$ Department of Atmospheric Sciences, University of Washington, Seattle, WA, USA \\ ${ }^{4}$ Department of Earth and Planetary Science, University of California, Berkeley, CA, USA \\ ${ }^{5}$ NOAA/ESRL Chemical Sciences Division, Boulder, CO, USA \\ ${ }^{6}$ Department of Environmental Science, Policy, and Management, University of California, Berkeley, Berkeley, CA, USA \\ ${ }^{7}$ Department of Meteorology, Penn State University, University Park, PA, USA \\ *now at: California Air Resources Board, Sacramento, CA, USA \\ ***w at: Rubenstein School of Marine and Atmospheric Science, University of Miami, Miami, FL, USA \\ **** now at: School of Engineering and Applied Sciences, Harvard University, Cambridge, MA, USA
}

Received: 1 April 2009 - Published in Atmos. Chem. Phys. Discuss.: 20 April 2009

Revised: 2 September 2009 - Accepted: 3 September 2009 - Published: 12 October 2009

\begin{abstract}
Acyl peroxy nitrates (APNs, also known as PANs) are formed from the oxidation of aldehydes and other oxygenated VOC (oVOC) in the presence of $\mathrm{NO}_{2}$. There are both anthropogenic and biogenic oVOC precursors to APNs, but a detailed evaluation of this chemistry against observations has proven elusive. Here we describe measurements of PAN, PPN, and MPAN along with the majority of chemicals that participate in their production and loss, including $\mathrm{OH}, \mathrm{HO}_{2}$, numerous oVOC, and $\mathrm{NO}_{2}$. Observations were made during the Biosphere Effects on AeRosols and Photochemistry Experiment (BEARPEX 2007) in the outflow of the Sacramento urban plume. These observations are used to evaluate a detailed chemical model of APN ratios and concentrations. We find that the ratios of APNs are nearly independent of the loss mechanisms and thus an especially good test of our understanding of their sources. We show that oxidation of methylvinyl ketone, methacrolein, methyl glyoxal, biacetyl and acetaldehyde are all significant sources of the PAN+peroxy acetyl (PA) radical reservoir, accounting for $26 \%, 2 \%, 7 \%, 20 \%$, and $45 \%$, of the production rate on
\end{abstract}

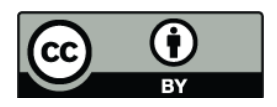

Correspondence to: J. A. Thornton (thornton@atmos.washington.edu) average during the campaign, respectively. At high temperatures, when upwind isoprene emissions are highest, oxidation of non-acetaldehyde PA radical sources contributes over $60 \%$ to the total PA production rate, with methylvinyl ketone being the most important of the isoprene-derived sources. An analysis of absolute APN concentrations reveals a missing APN sink that can be resolved by increasing the PA $+\Sigma \mathrm{RO}_{2}$ rate constant by a factor of 3 .

\section{Introduction}

Acyl peroxy nitrates (APNs, also known as PANs) are an important class of reactive nitrogen species having the general structure: $\mathrm{RC}(\mathrm{O}) \mathrm{OONO}_{2}$. In urban source regions, APN production acts as a net sink for $\mathrm{NO}_{\mathrm{x}}\left(\mathrm{NO}_{\mathrm{x}}=\mathrm{NO}+\mathrm{NO}_{2}\right)$. Under high $\mathrm{NO}_{\mathrm{x}}$ (VOC-limited) conditions this temporary sink results in increased ozone production rates by slowing the rate of $\mathrm{OH}$ reaction with $\mathrm{NO}_{2}$, and thus extending the $\mathrm{HO}_{\mathrm{x}}$ $\left(\mathrm{HO}_{\mathrm{x}}=\mathrm{OH}+\mathrm{HO}_{2}\right)$ chain length. Downwind of the source region, where total $\mathrm{NO}_{\mathrm{x}}$ levels have decreased, APN decomposition injects $\mathrm{NO}_{\mathrm{x}}$ into the atmosphere under low $\mathrm{NO}_{\mathrm{x}}$ conditions resulting in increased ozone production rates. This latter effect has been discussed extensively with respect to

Published by Copernicus Publications on behalf of the European Geosciences Union. 
production of ozone in the remote troposphere (Moxim et al., 1996; Kotchenruther et al., 2001; Hudman et al., 2004; Parrish et al., 2004), but it is also relevant to regions immediately outside of urban areas (Sillman and Samson, 1995; Olszyna et al., 1997; Lei et al., 2007).

APN formation is initiated by the reaction of the hydroxyl radical $(\mathrm{OH})$ with or by photolysis of aldehydes, ketones, and other oxygenated volatile organic compounds (oVOCs) (Reaction R1a and R1b). When the product of these reactions is an acyl peroxy (AP) radical with the general structure, $\mathrm{RC}(\mathrm{O}) \mathrm{O}_{2}$, then reversible reactions with $\mathrm{NO}_{2}$ to form APNs can occur (Reaction R2a and R2b).

$$
\begin{aligned}
& \mathrm{oVOC}+\mathrm{OH}\left(+\mathrm{O}_{2}\right) \longrightarrow \mathrm{RC}(\mathrm{O}) \mathrm{O}_{2} \\
& \mathrm{oVOC}+h v\left(+\mathrm{O}_{2}\right) \longrightarrow \mathrm{RC}(\mathrm{O}) \mathrm{O}_{2} \\
& \mathrm{RC}(\mathrm{O}) \mathrm{O}_{2}+\mathrm{NO}_{2} \longrightarrow \mathrm{RC}(\mathrm{O}) \mathrm{OONO}_{2} \\
& \mathrm{RC}(\mathrm{O}) \mathrm{OONO}_{2} \longrightarrow \mathrm{RC}(\mathrm{O}) \mathrm{O}_{2}+\mathrm{NO}_{2} \\
& \mathrm{RC}(\mathrm{O}) \mathrm{O}_{2}+\mathrm{NO} \longrightarrow \text { products } \\
& \mathrm{RC}(\mathrm{O}) \mathrm{O}_{2}+\mathrm{HO}_{2} \longrightarrow \text { products } \\
& \mathrm{RC}(\mathrm{O}) \mathrm{O}_{2}+\mathrm{RO}_{2} \longrightarrow \text { products } \\
& \mathrm{RC}(\mathrm{O}) \mathrm{OONO}_{2}+\mathrm{OH} \longrightarrow \text { products }
\end{aligned}
$$

There is a strong temperature dependence to the equilibrium between APNs and their AP radical intermediates $\left(\mathrm{RC}(\mathrm{O}) \mathrm{O}_{2}\right)$, and to the APN lifetime with respect to thermal decomposition. At high temperatures, the rapid equilibrium (Reaction R2) makes it useful to combine APNs and their corresponding AP radicals into a chemical family, denoted as $\mathrm{APN}_{T}$, as shown in Scheme 1a. In this situation, loss of $\mathrm{APN}_{T}$, and therefore APNs, is limited by reaction of the AP radical with $\mathrm{NO}$ (Reaction $\mathrm{R} 3$ ), $\mathrm{HO}_{2}$ (Reaction $\mathrm{R} 4$ ), or $\mathrm{RO}_{2}$ (Reaction R5). At low temperatures, equilibration within the $\mathrm{APN}_{T}$ reservoir is slower. In this situation, described by Scheme $1 \mathrm{~b}$, loss of $\mathrm{APN}_{T}$ is limited by the thermal decomposition rate of the APN and, in some cases, reaction of the APN with $\mathrm{OH}$.

In addition to gas phase chemical removal, the $\mathrm{APN}_{T}$ reservoir can be removed from the atmosphere by reactions in aerosol and fog (Roberts et al., 1996) or by dry deposition (Turnipseed et al., 2006; Farmer and Cohen, 2008; Wolfe et al., 2009). $\mathrm{APN}_{T}$ deposition can be an effective net sink for $\mathrm{NO}_{\mathrm{x}}$ if APNs are lost to surfaces, or it can serve as a source of $\mathrm{NO}_{\mathrm{x}}$ if deposition of the corresponding AP radical and concurrent release of $\mathrm{NO}_{\mathrm{x}}$ is important. APN deposition has been discussed as a potentially important source of nitrogen to plants (Sparks et al., 2003; Wolfe et al., 2009), with implications for ecosystem productivity (Magnani et al., 2007), soil acidification, and nitrate concentrations in run-off (Bytnerowicz and Fenn, 1996; Goulding et al., 1998).
Many APNs are associated with a single oVOC precursor. For example, peroxy propionyl nitrate (PPN) is believed to be exclusively derived from propanal and methacryloyl peroxy nitrate (MPAN) exclusively from methacrolein (Williams et al., 1997; Roberts et al., 2001). However, PAN, which typically comprises about $80 \%$ of the total speciated APNs (Roberts et al., 2007), has multiple oVOC sources. Detailed chemical mechanisms indicate that in addition to acetaldehyde, the isoprene oxidation products methyl glyoxal (MGLY), methylvinyl ketone (MVK), and methacrolein (MACR) are also potential sources of the peroxy acetyl (PA) radical, the precursor to PAN. Consistent with this expectation, Roberts et al. $(2001,2002)$ found that for Nashville, $\mathrm{TN}$, a region heavily impacted by isoprene emissions, production of PA radicals was significantly higher than could be accounted for by acetaldehyde alone. Observations of PAN off the coast of New England (Roberts et al., 2006) similarly showed a missing PA radical source that correlated with isoprene influence. A study using measurements of total peroxy nitrates ( $\Sigma$ PNs) and the individual precursor aldehydes at another isoprene-impacted site, immediately downwind of Sacramento, CA, led Cleary et al. (2007) to conclude that a PA radical source 3 times greater than that from acetaldehyde was necessary to bring their estimate of PAN/ $\Sigma$ PNs close to the $\sim 80 \%$ levels consistently reported elsewhere. Conversely, in Houston, TX, a heavily urbanized area with limited isoprene influence, PAN concentrations were consistent with an acetaldehyde source without the need for other oVOC (Roberts et al., 2001). Global modeling studies (Horowitz et al., 1998; Folberth et al., 2006) using explicit isoprene chemistry reach the same conclusion as the observational studies-that isoprene emissions are a significant driver of PAN production.

A different approach was taken by Grosjean et al. (2002), who used observations of VOCs from Porto Alegre, Brazil as inputs into the SAPRC 97 model and determined that a lumped class of reactive aromatic compounds was a significant contributor to a series of dicarbonyls, including methyl glyoxal, which will lead to PAN formation. No comparison of the model PAN output to observations was made in this study, nor has there been any other study, to date, that has verified the mechanisms of PA radical production by directly comparing PAN measurements to calculations based on the observed oVOC source distribution. With this in mind, the primary objective of this study is to evaluate a comprehensive chemical mechanism for production of the PA radical by comparison to observations. We approach this objective by making use of a steady-state model to determine whether mixing ratios of PAN, MPAN, and PPN, are in balance with their known sources and sinks. Cleary et al. (2007) evaluated a steady model of APNs against a time-dependent model and suggested that the lifetime of the $\mathrm{APN}_{T}$ reservoir is often short enough compared to the timescale for changes in its production rate, that a steady-state approximation will accurately describe APN mixing ratios. In contrast to the Cleary 
et al. (2007) study, which used the APN steady-state model to predict $\mathrm{OH}$ concentrations, the BEARPEX measurements include $\mathrm{OH}$ and $\mathrm{HO}_{2}$, thus providing an opportunity to thoroughly evaluate the APN steady-state model and to test the mechanisms of PA radical production.

\section{Experimental}

\subsection{Site description}

BEARPEX 2007 took place at a site on a ponderosa pine plantation owned and managed by Sierra Pacific Industries and adjacent to the University of California Blodgett Forest Research Station (UC-BFRS). The site is located 75 $\mathrm{km}$ northeast of Sacramento, CA (1315 ma.s.l., $38.9^{\circ} \mathrm{N}$, $\left.120.6^{\circ} \mathrm{W}\right)$. The experiment began on 15 August 2007 and ended on 10 October 2007.

Typical meteorological conditions at the site have been described in detail previously (Lamanna and Goldstein, 1999; Schade and Goldstein, 2001; Dillon et al., 2002; Kurpius and Goldstein, 2003; Holzinger et al., 2005; Cahill et al., 2006; Farmer et al., 2006; Day et al., 2008, 2009). Briefly, the meteorology during the dry season (May-September) is typified by high daytime temperatures, low rainfall, low humidity, clear skies, and extremely regular east/west, upslopedownslope winds. During the wet season (October-April), winds are less regular, temperatures are cooler, and there is moderate rainfall and snowfall (Goldstein et al., 2000). September 2007 was cooler than typical and there were early snows in October 2007.

Daytime winds carry anthropogenically influenced air from the Greater Sacramento Area, eastward up the slope of the Sierra Nevada. The region between Greater Sacramento and UC-BFRS is sparsely populated, and the plume develops with minor inputs from additional anthropogenic emissions as it travels towards UC-BFRS (Dillon et al., 2002; Murphy et al., 2006, 2007). The anthropogenic plume has a distinct arrival time at the measurement site in the late afternoon that changes very little from day to day. A $20-25 \mathrm{~km}$ wide band of oak woodlands runs parallel to the Sierra Nevada foothills and is perpendicular to the mean flow from Sacramento to UC-BFRS. In the morning, air that has relatively little urban influence passes over the forest and accumulates isoprene. This air arrives at UC-BFRS a few hours ahead of the anthropogenically influenced (but also isoprene rich) air. Local emissions from the ponderosa pines include 2methyl-3-buten-2-ol (MBO) (Schade et al., 2000) and significant amounts of monoterpenes, sesquiterpenes, and related oxygenates (Schade et al., 1999; Holzinger et al., 2005; Bouvier-Brown et al., 2008). Compared to the large injection of isoprene by the upwind oak woodlands, local isoprene emissions are small (Dreyfus et al., 2002).

A variety of long term and episodic measurements have been ongoing at the UC-BFRS site since 1997. During
BEARPEX 2007, measurements were greatly expanded over these previous experiments and included a range of anthropogenic and biogenic VOCs, $\mathrm{OH}, \mathrm{HO}_{2}, \mathrm{NO}_{\mathrm{x}}$ and other oxides of nitrogen $\left(\mathrm{NO}_{\mathrm{yi}}\right)$, peroxides, $\mathrm{CO}, \mathrm{O}_{3}, \mathrm{CO}_{2}$, aerosol composition and physical properties, and meteorological variables. Measurements used in this analysis were made from one of two walkup observation towers located $\sim 10 \mathrm{~m}$ apart. A complete overview of the campaign is given by Cohen and Goldstein (2009).

\subsection{Measurements}

In this analysis we use measurements of APNs, $\mathrm{OH}$ and $\mathrm{HO}_{2}$, a suite of VOCs, and $\mathrm{NO}_{2}$. The techniques and instruments used for these measurements have been described in detail previously. Speciated APN measurements were obtained via a custom-built thermal dissociation - chemical ionization mass spectrometer (TD-CIMS) (Wolfe et al., 2007, 2009). For this instrument, air was sampled from PFA inlets mounted on the North tower at $18 \mathrm{~m}$ through $30 \mathrm{~m}$ of tubing (residence time $\sim 2 \mathrm{~s}$ ) into a $19 \mathrm{~cm}$ length of $1 / 2^{\prime \prime}$ OD PFA tubing directly attached to the CIMS instrument and heated to $180^{\circ} \mathrm{C}$. At this temperature, APNs dissociate into $\mathrm{NO}_{2}$ and acyl peroxy radicals $\left(\mathrm{RC}(\mathrm{O}) \mathrm{O}_{2}\right)$ with $>95 \%$ efficiency. The hot sample gas then immediately passes through a critical orifice into an ion-molecule reaction region held at 60 Torr, where acyl peroxy radicals react with iodide to form carboxylate anions (Villalta and Howard, 1996; Slusher et al., 2004). Ions are transmitted through a collisional dissociation chamber into a quadrupole mass spectrometer where they are mass selected and detected.

In-situ calibrations and background determinations for the TD-CIMS were performed during the campaign using a photolytic PAN source and NO injection, respectively, as described by Wolfe et al. (2009). In CIMS, calibration constants are typically assumed to be similar between a family of compounds, and previous work has shown this to be true for most APNs with the exception of MPAN (Slusher et al., 2004). Post-campaign calibrations were done at NOAAESRL simultaneously with a gas chromatograph electron capture detection (GC/ECD) instrument (Roberts et al., 2002) and a $\mathrm{NO} / \mathrm{NO}_{2} / \mathrm{NO}_{\mathrm{y}}$ detector (Williams et al., 2000). Absolute concentrations of PAN, PPN, and MPAN from a stable diffusion source were verified using the $\mathrm{NO} / \mathrm{NO}_{2} / \mathrm{NO}_{\mathrm{y}}$ detector. These experiments confirmed that the University of Washington TD-CIMS is equally sensitive to PAN and PPN, but less sensitive to MPAN by a factor of 4.3. This relative insensitivity to MPAN is consistent across a number of TD-CIMS instruments (Slusher et al., 2004; Turnipseed et al., 2006) and was also observed for two other TD-CIMS instruments operated during these post-campaign experiments. While the precise chemical explanation for this artifact is unknown, by comparison with the GC/ECD instrument and the $\mathrm{NO} / \mathrm{NO}_{2} / \mathrm{NO}_{\mathrm{y}}$ measurements, it was concluded that this artifact is particular to the CIMS method and not an error in the 


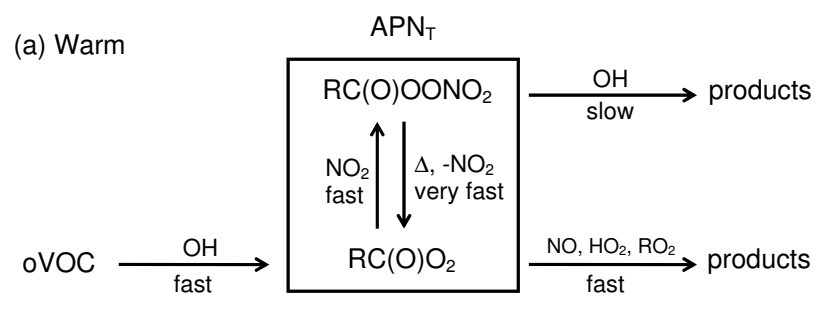

(b) Cold

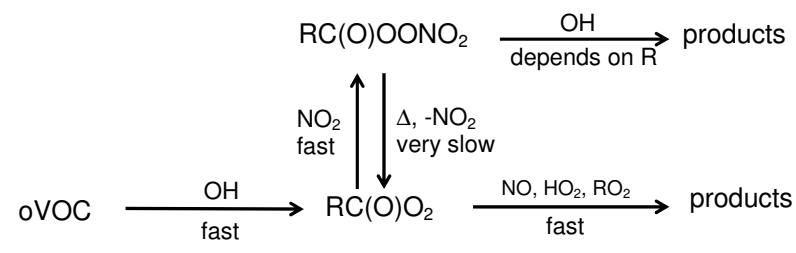

Scheme 1. 1 APN chemistry schematic under warm (a) and cold (b) conditions. $\mathrm{APN}_{T}$ is the sum of $\mathrm{APN}\left(\mathrm{RC}(\mathrm{O}) \mathrm{OONO}_{2}\right)$ and the $\mathrm{AP}$ radical $\left(\mathrm{RC}(\mathrm{O}) \mathrm{O}_{2}\right)$.

characterization of the standard MPAN calibration source, synthesized according to Bertman and Roberts (1991). Thus, the PAN sensitivity was applied to all three raw APN signals to yield concentrations, and the MPAN signal was further corrected for reduced sensitivity by a factor of 4.3. The measurements are accurate to $\pm 21 \%$ for PAN and PPN, and $\pm 31 \%$ for MPAN, where the larger total uncertainty results from the added uncertainty of the MPAN correction factor; the precision is \pm 3 pptv for half-hour averaged APN concentration measurements (Wolfe et al., 2009).

Measurements of acetaldehyde, propanal, biacetyl (2,3butanedione), methacrolein, methylvinyl ketone, isoprene and other organics were obtained on the same tower at $6 \mathrm{~m}$ using a 2-channel gas chromatograph/mass spectrometer (GC/MS) (Goldan et al., 2004; Bouvier-Brown et al., 2008). The accuracy of this measurement is $\pm 25 \%$ for oxygenated species and $\pm 15 \%$ for all other VOCs. $\mathrm{OH}$ and $\mathrm{HO}_{2}$ measurements were obtained at variable heights (from 2 to $15.5 \mathrm{~m}$ ) from a movable lift adjacent to the North tower. $\mathrm{OH}$ was measured by laser-induced fluorescence (LIF) at low pressure and $\mathrm{HO}_{2}$ was converted to $\mathrm{OH}$ through its reaction with $\mathrm{NO}$ followed by the LIF detection of OH (Faloona et al., 2004). The absolute uncertainty of $\mathrm{OH}$ and $\mathrm{HO}_{2}$ measurements is estimated to be $32 \%(2 \sigma)$. $\mathrm{NO}_{2}$ measurements were obtained by laser-induced fluorescence (Farmer et al., 2009; Fuchs et al., 2009), sampling at a height of $12 \mathrm{~m}$, also on the North tower. The accuracy of the LIF $\mathrm{NO}_{2}$ measurements during BEARPEX is estimated to be $10 \%$. Meteorological and ozone instrumentation is located on the South tower and is described in detail elsewhere (Goldstein et al., 2000). For our analysis we rely on photosynthetically active radiation (PAR) and temperature.
Unless otherwise noted, all data used in this analysis are 30 min averages of measurements and obtained between the hours of 12:00 and 17:00 PST, when observed oVOC concentrations are relatively constant. Concurrent measurements of all observations are available from 1 September 2007 to 24 September 2007, except for short periods where one or more instruments were offline for maintenance. Subsets of the measurements are available from 15 August 2007 to 10 October 2007.

\section{Kinetics of APNs}

\subsection{Steady-state model of APNs}

The chemistry of APNs and their corresponding AP radicals are summarized by Schemes 1a-b.

Concentrations of $\mathrm{APN}_{T}$ can be calculated by explicit integration of its production and loss rates as defined by Reaction (R1a) and Reactions (3-6), respectively (Eq. 1). Note that Reactions (R2a) and (R2b) are equilibration reactions within $\mathrm{APN}_{T}$ and do not lead to net loss or gain of $\mathrm{APN}_{T}$, and, as such, are not included in Eq. (1).

$$
\begin{aligned}
& {\left[\mathrm{APN}_{T}\right]=\int\left\{k_{1}[\mathrm{OH}(t)][\mathrm{oVOC}(t)]-k_{3}[\mathrm{AP}(t)][\mathrm{NO}(t)]\right\}} \\
& -k_{4}[\mathrm{AP}(t)]\left[\mathrm{HO}_{2}(t)\right]-k_{5}[\mathrm{AP}(t)]\left[\mathrm{RO}_{2}(t)\right] \\
& \left\{-k_{6}[\mathrm{APN}(t)][\mathrm{OH}(t)]\right\} d t
\end{aligned}
$$

Regardless of the thermal decomposition rate of APN, the AP radical can usually be treated in steady-state since its lifetime is very short $(\tau \sim 0 \mathrm{~s})$ relative to typical changes in [oVOC]. [AP], therefore, can be calculated by Eq. (2).

$$
[\mathrm{AP}]_{s s}=\frac{k_{1}[\mathrm{OH}][\mathrm{oVOC}]+k_{2 b}[\mathrm{APN}]}{k_{2 a}\left[\mathrm{NO}_{2}\right]+k_{3}[\mathrm{NO}]+k_{4}\left[\mathrm{HO}_{2}\right]+k_{5}\left[\mathrm{RO}_{2}\right]}
$$

The expression for $\left[\mathrm{APN}_{T}\right]$ (Eq. 3) can be simplified by combining Eqs. ( 1 and 2 ) and introducing the term, $\beta \mathrm{g}$ Eq. (4), which has a value between 0 and 1 that represents the probability that the AP radical will react with $\mathrm{NO}_{2}$, to give an APN, over an irreversible reaction with $\mathrm{NO}, \mathrm{HO}_{2}$, or $\mathrm{RO}_{2}$, to give other products (Roberts et al., 2001). The lifetime of $\mathrm{APN}_{T}$, therefore, is dependent not only upon the thermal decomposition of the APN, but also the value of $\beta$. Equation (3) can be used to accurately calculate $\left[\mathrm{APN}_{T}\right]$, provided one has knowledge of the temporal variation of the oVOC source molecule, $\beta$, and $\mathrm{OH}$.

$$
\begin{aligned}
& {\left[\operatorname{APN}_{T}\right]=\int\left\{\beta(t) k_{1}[\mathrm{OH}(t)][\mathrm{oVOC}(t)]-(1-\beta) k_{2 b}(t)\right\}} \\
& \left\{[\mathrm{APN}(t)]-k_{6}[\mathrm{APN}(t)][\mathrm{OH}(t)]\right\} d t \\
& \beta=\frac{k_{2 a}\left[\mathrm{NO}_{2}\right]}{k_{2 a}\left[\mathrm{NO}_{2}\right]+k_{3}[\mathrm{NO}]+k_{4}\left[\mathrm{HO}_{2}\right]+k_{5}\left[\mathrm{RO}_{2}\right]}
\end{aligned}
$$

When $\mathrm{APN}_{T}$ is in steady-state with its sources and sinks, Eq. (3) can be further simplified as shown in Eq. (4) where 
we also note that when $[\mathrm{AP}] \ll[\mathrm{APN}],[\mathrm{APN}]$ is approximately equal to $\left[\mathrm{APN}_{T}\right]$.

$[\mathrm{APN}] \cong\left[\mathrm{APN}_{T}\right]=\frac{\beta k_{1}[\mathrm{OH}][\mathrm{oVOC}]}{k_{2 b}(1-\beta)+k_{6}[\mathrm{OH}]}$

The relationship between the steady-state (Eq. 5) and timedependent (Eq. 3) models was discussed by Cleary et al. (2007). Equation (4) is a good approximation of Eq. (3) when changes in the $\mathrm{APN}_{T}$ loss and production rates are small on the time scale of the $\mathrm{APN}_{T}$ lifetime. To demonstrate, we integrate Eq. (3) to give Eq. (5), subject to assumptions that $\mathrm{OH}$ and $\beta$ are constant with time. Equation (5) describes the time-dependent behavior for a hypothetical APN, $\mathrm{APN}_{A}$, having a precursor, $\mathrm{oVOC}_{\mathrm{A}} \cdot[\mathrm{APN}]_{\mathrm{o}}$ and $[\mathrm{oVOC}]_{\mathrm{o}}$ in Eq. (5) are the initial concentrations in the model (at $\mathrm{t}=0$ ). The dependence of $\mathrm{APN}_{T A}$ on the history of $\mathrm{oVOC}_{\mathrm{A}}$ is contained in the term: $(1-\mathrm{P} / \mathrm{L}) \times k_{1 \mathrm{~A}}[\mathrm{OH}]$, where $\mathrm{P} / \mathrm{L}$ is the ratio of $\mathrm{OVOC}_{\mathrm{A}}$ production to loss and $\mathrm{oVOC}_{\mathrm{A}}$ loss is presumed to be exclusively via $\mathrm{OH}$ reaction. When $\mathrm{P} / \mathrm{L}$ is 0 (i.e. when $\mathrm{P}=0),\left[\mathrm{oVOC}_{\mathrm{A}}\right]$ is decreasing exponentially according to its reaction with $[\mathrm{OH}]$. When $\mathrm{P} / \mathrm{L}=1$ (i.e. $\mathrm{P}=\mathrm{L}$ ), production balances loss and $\left[\mathrm{oVOC}_{\mathrm{A}}\right]$ is constant with time.

$$
\begin{aligned}
& {\left[\mathrm{APN}_{T_{A}}\right]=\frac{\beta k_{1 \mathrm{~A}}[\mathrm{OH}]\left[\mathrm{oVOC}_{\mathrm{A}}\right]}{k_{2 b}(1-\beta)+k_{6}[\mathrm{OH}]-\left(1-\frac{\mathrm{P}}{\mathrm{L}}\right) k_{1 a}[\mathrm{OH}]}} \\
& {\left[1-e^{t\left(\left(1-\frac{\mathrm{P}}{\mathrm{L}}\right) k_{1 \mathrm{~A}}[\mathrm{OH}]-k_{2 \mathrm{~b}}(1-\beta)-k_{6}[\mathrm{OH}]\right)}\right]} \\
& +\left[\mathrm{APN}_{T_{A}}\right]_{0} \frac{\left[\mathrm{oVOC}_{\mathrm{A}}\right]}{\left[\mathrm{oVOC}_{\mathrm{A}}\right]_{0}} \\
& e^{t\left(\left(1-\frac{\mathrm{P}}{\mathrm{L}}\right) k_{1 \mathrm{~A}}[\mathrm{OH}]-k_{2 \mathrm{~b}}(1-\beta)-k_{6}[\mathrm{OH}]\right)}
\end{aligned}
$$

Note that Eq. (5) is modified slightly from that used by Roberts et al. (2001) who assume in all cases an exponential decay in oVOC concentrations from the point of emissions, giving $\mathrm{P} / \mathrm{L}=0$. Typical oVOC precursors of APNs, such as acetaldehyde, methacrolein, and propanal, are produced as a result of VOC- $-\mathrm{HO}_{\mathrm{x}}-\mathrm{NO}_{\mathrm{x}}$ cycling on the timescale of hours. Calculations show that $\mathrm{P} / \mathrm{L} \neq 0$ for these APN precursors, at least in the near-field (tens of $\mathrm{km}$ ) with respect to VOC emission sources (see Sect. 5).

In accord with the findings of Cleary et al. (2007) it can be seen that in the case where $\mathrm{P} / \mathrm{L}=1$, the time-dependent equation takes the form of the instantaneous steady-state equation (Eq. 6) at the limit of $t=\infty$. However, in the case where $\mathrm{P} / \mathrm{L}=0$, the lifetime of $\mathrm{oVOC}_{\mathrm{A}}$ is often short enough that the $\mathrm{APN}_{T}$ production term is decaying rapidly relative to the lifetime of $\mathrm{APN}_{T A}$. In this case, there will be significant deviations between a time-dependent solution for $\left[\mathrm{APN}_{T A}\right]$ and an approximation based on steady-state assumptions, even as $t$ approaches infinity. This dependence on the behavior of oVOCs is reduced as the $\mathrm{APN}_{T}$ lifetime gets shorter. We also find that steady-state conditions are more likely to apply to the $\mathrm{APN}_{T}$ system when temperatures are high and thermal decomposition is fast.

\subsection{Steady-state model of APN concentration ratios}

It is commonly assumed that the APN thermal decomposition rate constant $\left(k_{2 b}\right)$ and the reactivity of acyl peroxy radicals $\left(k_{3}, k_{4}\right.$, and $\left.k_{5}\right)$ are relatively independent of the identity of the APN alkyl group. Kirchner et al. (1999) report differences of order $25 \%$ across a series of acyl peroxy nitrates. Given this similar reactivity, it can be instructive to analyze the ratios of APNs to gain insight into the behavior of their oVOC sources. Applying the steady-state equation (Eq. 5) to the concentration of two different APNs, we derive an expression (Eq. 7) for the ratio of $\mathrm{APN}_{T A}$ to $\mathrm{APN}_{T B}$.

$\frac{\left[\mathrm{APN}_{T_{A}}\right]}{\left[\mathrm{APN}_{T_{B}}\right]}=\frac{k_{1 \mathrm{~A}}\left[\mathrm{oVOC}_{\mathrm{A}}\right]}{k_{1 \mathrm{~B}}\left[\mathrm{oVOC}_{\mathrm{B}}\right]} \times \frac{(1-\beta) k_{2 \mathrm{bB}}+k_{6 \mathrm{~B}}[\mathrm{OH}]}{(1-\beta) k_{2 \mathrm{bA}}+k_{6 \mathrm{~A}}[\mathrm{OH}]}$

This expression can be further simplified, with the assumption that $k_{2 \mathrm{~b}}$ is identical for both APNs and that loss of both APNs by reaction with $\mathrm{OH}$ occurs at rates that are each much slower than the loss to reaction with $\mathrm{NO}, \mathrm{HO}_{2}$, and $\mathrm{RO}_{2}$ (given by $(1-\beta) k_{2 \mathrm{~b}}$ ). With these assumptions, the second term in Eq. (6) cancels and the ratio is approximately Eq. (7).

$\frac{\left[\mathrm{APN}_{T_{A}}\right]}{\left[\mathrm{APN}_{T_{B}}\right]} \approx \frac{k_{1 \mathrm{~A}}\left[\mathrm{oVOC}_{\mathrm{A}}\right]}{k_{1 \mathrm{~B}}\left[\mathrm{oVOC}_{\mathrm{B}}\right]}$

Analysis of Eqs. (6 and 7) indicates that APN ratios are primarily dependent on the ratio of their oVOC precursors. In addition, APN ratios will be accurately predicted as long as the ratio of the precursor oVOCs is not changing rapidly relative to the $\mathrm{APN}_{T}$ lifetimes (e.g. the steady state assumptions for $\mathrm{APN}_{T}$ ratios are accurate) and as long as the rate of APN loss to OH (Reaction R6) is slow relative to thermal decomposition followed by loss of the AP radical. Calculations indicate that this result holds over a wider range of temperatures and source conditions than was described by Cleary et al. (2007) for absolute concentrations.

As with absolute concentrations, these assumptions about a steady-state approximation for APN ratios can be tested by comparing the instantaneous steady-state equation (Eq. 7) with numerical integration of the time-dependent equations for two hypothetical APNs, $\mathrm{APN}_{A}$ and $\mathrm{APN}_{B}$. For simplicity, we assume that both APNs each have single oVOC precursors, that both do not have any appreciable loss to reaction with $\mathrm{OH}$, that their decomposition rates are identical, and that initial $\mathrm{APN}_{T}$ concentrations are 0 . Under these conditions, the time-dependent ratio of $\mathrm{APN}_{T A}$ to $\mathrm{APN}_{T B}$ will be described by Eq. (8).

$$
\begin{aligned}
& \frac{\left[\mathrm{APN}_{T_{A}}\right]}{\left[\mathrm{APN}_{T_{B}}\right]}=\frac{k_{1 \mathrm{~A}}\left[\mathrm{oVOC}_{\mathrm{A}}\right]}{k_{1 \mathrm{~B}}\left[\mathrm{oVOC}_{\mathrm{B}}\right]} \times \frac{k_{2 \mathrm{~b}}(1-\beta)-\left(1-\frac{\mathrm{P}}{\mathrm{L}}\right) k_{1 \mathrm{~B}}[\mathrm{OH}]}{k_{2 \mathrm{~b}}(1-\beta)-\left(1-\frac{\mathrm{P}}{\mathrm{L}}\right) k_{1 \mathrm{~A}}[\mathrm{OH}]} \\
& \times \frac{1-e^{t\left(\left(1-\frac{\mathrm{P}}{\mathrm{L}}\right) k_{1 \mathrm{~A}}[\mathrm{OH}]-k_{2 \mathrm{~b}}(1-\beta)\right)}}{1-e^{t\left(\left(1-\frac{\mathrm{P}}{\mathrm{L}}\right) k_{1 \mathrm{~B}}[\mathrm{OH}]-k_{2 \mathrm{~b}}(1-\beta)\right)}}
\end{aligned}
$$

This time-dependent ratio is dependent upon the ratio of source terms, as in Eq. (7), but it is also sensitive to $\mathrm{OH}$ concentrations, $\beta$ and to temperature when $k_{1 \mathrm{~A}}$ and $k_{1 \mathrm{~B}}$ are appreciably different and when $\mathrm{P} / \mathrm{L} \neq 1$. However, when $\mathrm{P} / \mathrm{L}=1$ 
(a)

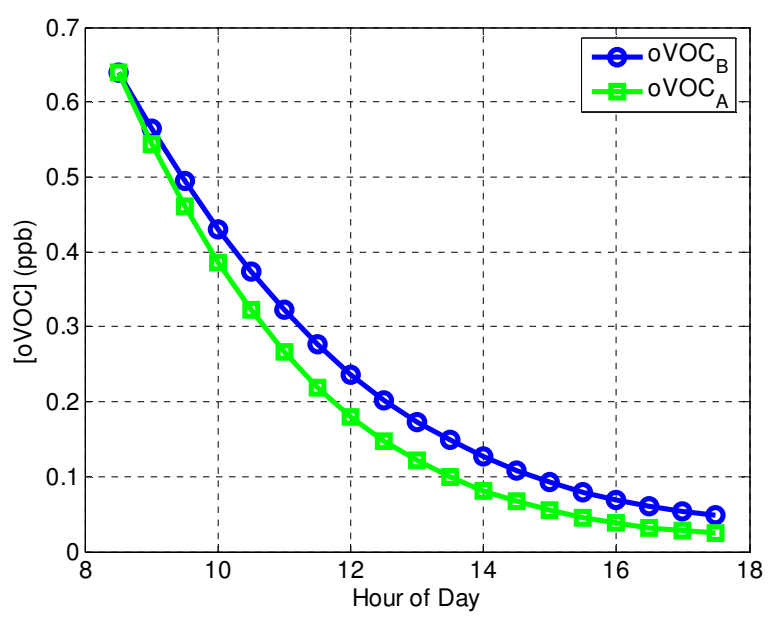

(b)

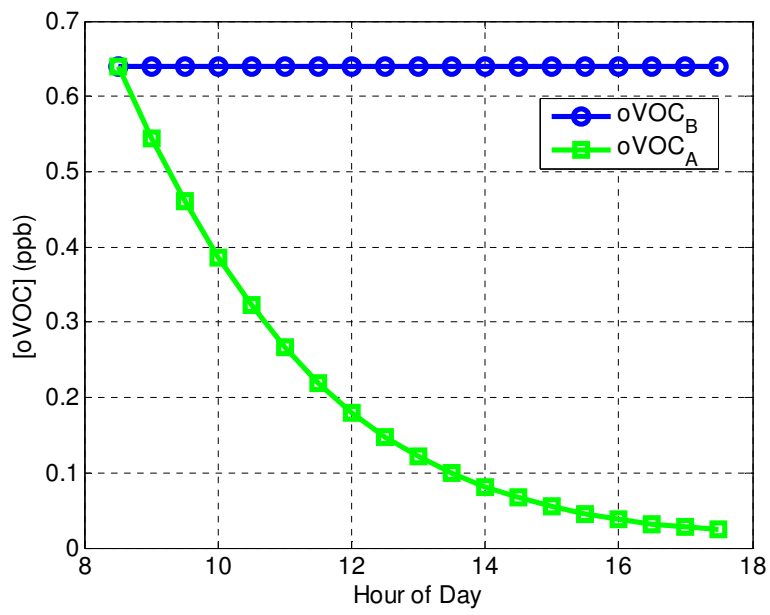

Fig. 1. oVOC profiles for time-dependent simulations of APNs: (a) Case A: both oVOCs decreasing exponentially with e-folding lifetimes of $\sim 2.5\left(\mathrm{oVOC}_{\mathrm{A}}\right)$ and $\sim 3.5 \mathrm{~h}\left(\mathrm{oVOC}_{\mathrm{B}}\right)$ with no production $(\mathrm{P} / \mathrm{L}=0)$ and (b) Case $\mathrm{B}$ : oVOC $_{\mathrm{A}}$ decreasing as in scenario $\mathrm{A}$, and $\mathrm{oVOC}_{\mathrm{B}}$ having equal production and loss rates $(\mathrm{P} / \mathrm{L}=1)$.

for both oVOCs or if the differences in $k_{1 \mathrm{~A}}$ and $k_{1 \mathrm{~B}}$ are offset by differences in $(\mathrm{P} / \mathrm{L})_{\mathrm{A}}$ and $(\mathrm{P} / \mathrm{L})_{\mathrm{B}}$ Eq. (8) reduces to the steady-state approximation (Eq. 8) at $\mathrm{t}=\infty$. Thus, if $\mathrm{oVOC}_{\mathrm{A}}$ and $\mathrm{oVOC}$ B have similar sources and sinks, the ratio of $\mathrm{APN}_{T A}$ to $\mathrm{APN}_{T B}$ is accurately approximated by the steady-state equation.

The effect of differences in the relative behavior of the oVOCs on APN ratios is illustrated with two examples: (A) both oVOC precursors are allowed to decrease exponentially due to their loss to $\mathrm{OH}$ (Fig. 1a) and (B) oVOC $\mathrm{A}$ decreases exponentially and $\mathrm{oVOC}_{\mathrm{B}}$ remains constant (Fig. 1b). In case $\mathrm{A}$, at equilibrium $(\mathrm{t}=\infty)$, the agreement between steady-state and time-dependent predictions is determined by the ratio of rate constants $k_{1 \mathrm{~A}}$ and $k_{1 \mathrm{~B}}$, but only to the extent that this ra-

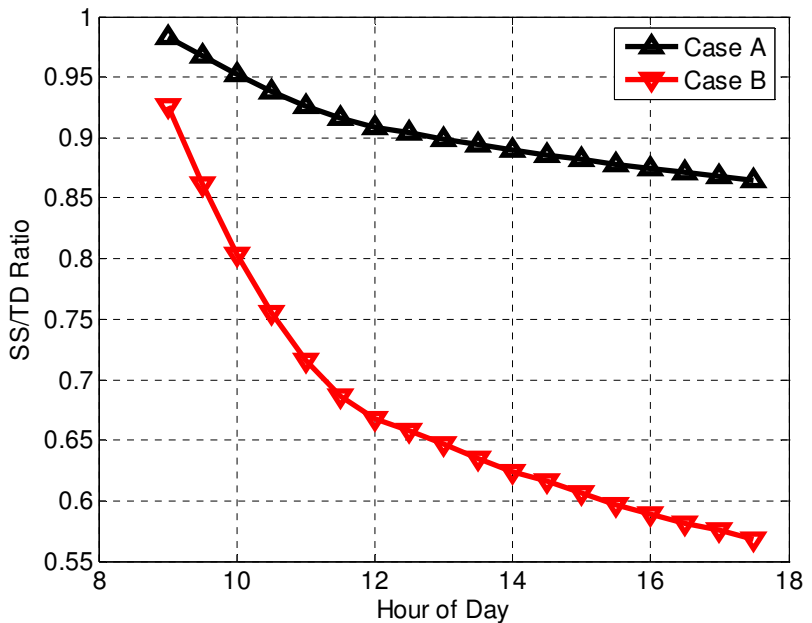

Fig. 2. Ratio of results from steady-state (SS) to time-dependent (TD) model for predicting the ratio of $\mathrm{APN}_{A} / \mathrm{APN}_{B}$ for the two different cases of oVOC behavior described in the text and illustrated in Fig. 1a-b.

tio changes the $\left[\mathrm{oVOC}_{\mathrm{A}}\right] /\left[\mathrm{oVOC}_{\mathrm{B}}\right]$ ratio on a time scale that is of the same order as $\mathrm{APN}_{T}$ loss. In case $\mathrm{B}$, the added production of $\mathrm{oVOC}_{\mathrm{B}}$ causes a change in the $\mathrm{oVOC}_{\mathrm{A}} / \mathrm{oVOC}_{\mathrm{B}}$ ratio with time, with effects on $\mathrm{APN}_{T}$ ratios that depend on the lifetime of $\mathrm{APN}_{T}$.

To demonstrate, we use a case where $\mathrm{APN}_{T}$ lifetimes are about $70 \mathrm{~min}$, and $k_{1 \mathrm{a}}$ and $k_{1 \mathrm{~b}}$ are equal to the rate constants for propanal and acetaldehyde (see Table 1), respectively. We initialize the time-dependent model at 9am, and the variables $\left[\mathrm{HO}_{2}\right],\left[\mathrm{RO}_{2}\right],[\mathrm{NO}],\left[\mathrm{NO}_{2}\right],[\mathrm{OH}]$, and $\mathrm{T}$ are given diurnal behavior typical of the UC-BFRS measurement site. The results are shown in Fig. 2, where the steady-state predictions of $\mathrm{APN}_{T A} / \mathrm{APN}_{T B}$ are plotted relative to the time-dependent predictions versus time of day. By noon, the system reaches a stationary state and remains there until about 17:00, at which time $\beta$ is changing rapidly. For both cases, at all times of day, the steady-state to time-dependent ratio is seen diverging from 1 as a result of a continuously changing ratio of $\mathrm{oVOC}_{\mathrm{A}}$ to $\mathrm{oVOC}_{\mathrm{B}}$. While the system never reaches the exact steadystate, the differences are tolerable when the divergence from steady-state is slow. For example, in Case A, the steady-state model for $\mathrm{APN}_{T A} / \mathrm{APN}_{T B}$ is lower than the time-dependent model by $10-15 \%$ throughout the afternoon. Case A, which represents a scenario where two oVOC precursors have similar production and loss terms, is likely, therefore, to result in a steady-state prediction of $\mathrm{APN}_{T}$ ratios that is accurate to $15 \%$. When the behavior of oVOCs is very different, however, the agreement between time-dependent and steady-state predictions of the ratio worsens. As shown in Fig. 2, the steady-state model is in agreement with the time dependent one to within about $35-45 \%$ in Case B. From this analysis, we conclude that an e-fold change in the oVOC ratio over 
150 min will result in a steady-state approximation accurate to $45 \%$ or better when the $\mathrm{APN}_{T}$ lifetimes are $70 \mathrm{~min}$. A faster change in oVOC ratios would become tolerable with a corresponding decrease in $\mathrm{APN}_{T}$ lifetime.

If we now consider a third APN, $\mathrm{APN}_{C}$, which has an appreciable loss rate to reaction with $\mathrm{OH}$, the time-dependent model for the ratio of $\mathrm{APN}_{T C}$ to $\mathrm{APN}_{T A}$ or $\mathrm{APN}_{T B}$ will become more sensitive to the individual rates of change of each oVOC precursor, as opposed to changes in the oVOC ratios. This results from the lack of cancellation of the loss terms for the two APNs in Eq. (8). Steady-state predictions of absolute concentrations of $\mathrm{APN}_{T C}$ will be more accurate due to the shorter $\mathrm{APN}_{T C}$ lifetime, but the accuracy of the steady-state model in predicting $\mathrm{APN}_{T C} / \mathrm{APN}_{T A}$ and $\mathrm{APN}_{T C} / \mathrm{APN}_{T B}$ may be degraded. For comparison to the scenarios above, we assume the same conditions as in cases A and B and that the loss of $\mathrm{APN}_{C}$ to $\mathrm{OH}$ is about $40 \%$ of the total $\mathrm{APN}_{T}$ loss rate $\left(\tau_{\mathrm{R} 6} \sim 90 \mathrm{~min}\right.$ and $\left.\tau_{\mathrm{R} 2 \mathrm{~b}+\mathrm{R} 35} \sim 70 \mathrm{~min}\right)$. Although the above analysis suggests some degradation of the accuracy of the steady-state approximation for the ratio, we find the steady-state predictions of ratios of $\mathrm{APN}_{T C} / \mathrm{APN}_{T A}$ or $\mathrm{APN}_{T C} / \mathrm{APN}_{T B}$ (Eq. 7) to be within $10 \%$ of the predictions for $\mathrm{APN}_{T A} / \mathrm{APN}_{T B}$ in both cases $\mathrm{A}$ and $\mathrm{B}$.

Our conclusions on the accuracy of the steady-state model under these various scenarios of oVOC behavior are summarized in Table 2.

\subsection{Application of the steady-state model to MPAN, PPN, and PAN at UC-BFRS}

Application of the steady-state model to specific APNs requires defining the production and loss terms for each APN.

\subsubsection{MPAN, PPN, and PAN loss}

Three important reactants for acyl peroxy radicals are NO, $\mathrm{HO}_{2}$, and organic peroxy radicals $\left(\mathrm{RO}_{2}\right)$. NO concentrations are inferred by assuming a photo-stationary state relationship between $\mathrm{NO}_{2}$, ozone, and peroxy radicals $\left(\mathrm{HO}_{2}+\mathrm{RO}_{2}\right)$ through the following equation:

$$
[\mathrm{NO}]=\frac{\mathrm{J}_{\mathrm{NO}_{2}}\left[\mathrm{NO}_{2}\right]}{k_{\mathrm{HO}_{2}+\mathrm{NO}}\left[\mathrm{HO}_{2}\right]+k_{\mathrm{RO}_{2}+\mathrm{NO}}\left[\mathrm{RO}_{2}\right]+k_{\mathrm{NO}+\mathrm{O}_{3}}\left[\mathrm{O}_{3}\right]}
$$

The photolysis rate of $\mathrm{NO}_{2}\left(\mathrm{~J}_{\mathrm{NO} 2}\right)$ is obtained from the TUV model (Madronich, 1987), calculated with varying solar zenith angles at half hour intervals over the entire campaign while holding other parameters constant (cloud optical depth=0; aerosol optical depth $=0.235$; ozone column $=300$ Dobson units; single scattering aerosol albedo $=0.990$ ). The model output was scaled by measured PAR to account for the occasional periods of cloud cover. The rate constants used for calculating [NO] are listed in Table 1.

$\mathrm{RO}_{2}$ concentrations are estimated through a separate steady-state relationship where production occurs from the reaction of $\mathrm{OH}$ with a suite of VOCs and loss is due to reaction with $\mathrm{NO}, \mathrm{HO}_{2}$, and other $\mathrm{RO}_{2}$ radicals. This relationship leads to Eq. (10), which can be reduced to a quadratic equation.

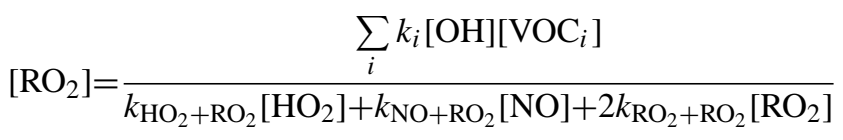

Equations (9 and 10) are solved iteratively until values of $\mathrm{NO}$ and $\mathrm{RO}_{2}$ are obtained with convergence criteria of $<1 \%$ precision. An uncertainty of a factor of 2 in either $\mathrm{RO}_{2}$ or $\mathrm{NO}$ concentrations propagates into an additional uncertainty of $15-20 \%$ in the other radical.

Thermal decomposition rates of PAN and MPAN are considered to be the same in this analysis. Decomposition of PPN, however, is measured to be $25 \%$ slower (at $298 \mathrm{~K}$ and $1 \mathrm{~atm}$ ) by Kirchner et al. (1999). Reactions of acyl peroxy radicals (with $\mathrm{NO}, \mathrm{NO}_{2}, \mathrm{HO}_{2}$, or $\mathrm{RO}_{2}$ ) are generally considered to be independent of $\mathrm{R}$ group (Roberts and Bertman, 1992). An additional difference in the chemical removal of the various APNs is reaction with $\mathrm{OH}$. Of the three APNs that we are considering, only MPAN has an appreciable loss rate to reaction with $\mathrm{OH}(\tau \sim 2 \mathrm{~h}$ for $[\mathrm{OH}]=5 \times 10^{6}$ molecules $\mathrm{cm}^{-3}$ ), stemming from an alkene moiety (Orlando et al., 2002). PPN and PAN, in contrast, have lifetimes on the order of weeks to months with respect to $5 \times 10^{6}$ molecules $\mathrm{cm}^{-3} \mathrm{OH}$. $\mathrm{APN}_{T}$ deposition velocities are on the order of $10^{-1} \mathrm{~cm} \mathrm{~s}^{-1}\left(\tau_{\mathrm{dep}} \sim 20-100 \mathrm{~h}\right.$ ) (Wolfe et al., 2009), making deposition a 2-6\% per hour sink, small enough to neglect in this analysis.

\subsubsection{MPAN, PPN, and PAN production}

Production of MPAN ${ }_{T}$ occurs by abstraction of the aldehydic hydrogen from methacrolein during reaction with $\mathrm{OH}$, followed by the effectively instantaneous addition of $\mathrm{O}_{2}$. Equation (12), then, describes $\mathrm{MPAN}_{T}$ production rate:

$P\left(\mathrm{MPAN}_{T}\right)=\alpha_{\text {macr }} k_{1 \text { macr }}[\mathrm{OH}][\mathrm{MACR}]$,

where $\alpha$ represents the aldehydic abstraction branching ratio from the reaction of methacrolein (MACR) with $\mathrm{OH}$ $\left(\alpha_{\text {macr }}=0.45\right)$ and $k_{1 \text { macr }}$ represents the rate coefficient for the total reaction of $\mathrm{OH}+\mathrm{MACR}$.

Similarly, production of $\mathrm{PPN}_{T}$ occurs from the abstraction of the aldehydic hydrogen from propanal. The branching ratio for this process $\left(\alpha_{\text {propanal }}\right)$ is $\sim 1$ since the aldehydic $\mathrm{H}$ is the only appreciably reactive functionality.

$P\left(\mathrm{PPN}_{T}\right)=\alpha_{\text {propanal }} k_{1 \text { propanal }}[\mathrm{OH}][$ propanal $]$

Production of PAN $\mathrm{P}_{T}$ occurs upon oxidation of acetaldehyde (acetal) (Carter, 1990), methyl glyoxal (MGLY) (Romero et al., 2005; Baeza-Romero et al., 2007), methacrolein (MACR) (Orlando et al., 1999), and methylvinyl ketone (MVK) (Tuazon and Atkinson, 1989), and through the photolysis of biacetyl (biacet) (Carter, 1990; Klotz et al., 2001). 
Table 1. Rate constants used in analysis.

\begin{tabular}{|c|c|c|c|c|}
\hline & $k(T)$ or $k(T,[\mathrm{M}])^{\mathrm{a}}$ & $k(298 \mathrm{~K})$ & $\alpha^{\mathrm{b}}$ & Reference \\
\hline \multicolumn{5}{|l|}{$\mathrm{VOC}+\mathrm{OH}$ reactions } \\
\hline methacrolein & $8.0 \times 10^{-12} \exp (380 / \mathrm{T})$ & $2.9 \times 10^{-11}$ & 0.45 & (Atkinson et al., 2006) \\
\hline acetaldehyde & $4.4 \times 10^{-12} \exp (365 / \mathrm{T})$ & $1.5 \times 10^{-11}$ & 1 & (Atkinson et al., 2006) \\
\hline propanal & $5.1 \times 10^{-12} \exp (405 / \mathrm{T})$ & $2.0 \times 10^{-11}$ & 1 & (Atkinson et al., 2006) \\
\hline methyl glyoxal & $1.83 \times 10^{-12} \exp (560 / \mathrm{T})$ & $1.2 \times 10^{-11}$ & 1 & (Baeza-Romero et al., 2007) \\
\hline methyl vinyl ketone & $2.6 \times 10^{-12} \exp (610 / \mathrm{T})$ & $2.0 \times 10^{-11}$ & N/A & (Atkinson et al., 2006) \\
\hline \multicolumn{5}{|l|}{ Acyl Peroxy Radical reactions } \\
\hline $\mathrm{RCOO}_{2}+\mathrm{NO}_{2} \longrightarrow \mathrm{APN}(\mathrm{R} 2 \mathrm{a})$ & $\begin{array}{l}k_{0}=2.7 \times 10^{-28}(\mathrm{~T} / 300)^{-7.1} \\
k_{\infty}=1.2 \times 10^{-11}(\mathrm{~T} / 300)^{-0.9} \\
\mathrm{~F}_{\text {cent }}=0.3 \\
\mathrm{~N}=1\end{array}$ & $1.0 \times 10^{-11}$ & N/A & (Atkinson et al., 1997, 2004) \\
\hline $\mathrm{APN} \longrightarrow \mathrm{RCOO}_{2}+\mathrm{NO}_{2}(\mathrm{R} 2 \mathrm{~b})$ & $\begin{array}{l}k_{0}=4.9 \times 10^{-3} \exp (-12100 / \mathrm{T}) \\
k_{\infty}=4.0 \times 10^{16} \exp (-13600 / \mathrm{T}) \\
\mathrm{F}_{\text {cent }}=0.3 \\
\mathrm{~N}=1.41\end{array}$ & $4.6 \times 10^{-04}$ & N/A & (Atkinson et al., 1997, 2004) \\
\hline $\mathrm{PPN} \longrightarrow \mathrm{C}_{2} \mathrm{H}_{5} \mathrm{COO}_{2}+\mathrm{NO}_{2}$ & $\begin{array}{l}k_{0}=1.7 \times 10^{-3} \exp (-11280 / \mathrm{T}) \\
k_{\infty}=4.0 \times 10^{16} \exp (-13940 / \mathrm{T}) \\
\mathrm{F}_{\text {cent }}=0.36 \\
\mathrm{~N}=1.41\end{array}$ & $4.6 \times 10^{-04}$ & N/A & (Kirchner et al., 1999) \\
\hline $\mathrm{RCOO}_{2}+\mathrm{NO} \longrightarrow$ products (R3) & $8.1 \times 10^{-12} \exp (270 / \mathrm{T})$ & $2.0 \times 10^{-11}$ & N/A & (Atkinson et al., 1997, 2004) \\
\hline $\mathrm{RCOO}_{2}+\mathrm{HO}_{2} \longrightarrow$ products (R4) & $4.3 \times 10^{-13} \exp (1040 / \mathrm{T})$ & $1.4 \times 10^{-11}$ & N/A & $(\mathrm{MCM}, 2003)$ \\
\hline $\mathrm{RCOO}_{2}+\mathrm{RO}_{2} \longrightarrow$ products (R5) & $2.0 \times 10^{-12} \exp (500 / \mathrm{T})$ & $1.1 \times 10^{-11}$ & N/A & (Tyndall, 2001) \\
\hline \multicolumn{5}{|l|}{$A P N+O H$ reactions } \\
\hline PAN & N/A & $3 \times 10^{-14}$ & N/A & (Talukdar et al., 1995) \\
\hline PPN & N/A & $3 \times 10^{-13}$ & N/A & Estimated from (Carter and Atkinson, 1985) \\
\hline MPAN & N/A & $32 \times 10^{-12}$ & N/A & (Orlando et al., 2002) \\
\hline \multicolumn{5}{|l|}{ HOx and NOx reactions } \\
\hline $\mathrm{HO}_{2}+\mathrm{RO}_{2}$ & $2.9 \times 10^{-13} \exp (1300 / \mathrm{T})$ & $2.3 \times 10^{-11}$ & N/A & (MCM, 2003) \\
\hline $\mathrm{RO}_{2}+\mathrm{RO}_{2}$ & N/A & $2.4 \times 10^{-12}$ & N/A & (MCM, 2003) \\
\hline $\mathrm{NO}+\mathrm{RO}_{2}$ & $2.54 \times 10^{-12} \exp (360 / \mathrm{T})$ & $8.5 \times 10^{-12}$ & N/A & (MCM, 2003) \\
\hline $\mathrm{NO}+\mathrm{HO}_{2}$ & $3.5 \times 10^{-12} \exp (250 / \mathrm{T})$ & $8.1 \times 10^{-12}$ & N/A & (NASA, 2006) \\
\hline $\mathrm{NO}+\mathrm{O}_{3}$ & $3.0 \times 10^{-12} \exp (-1500 / \mathrm{T})$ & $2.0 \times 10^{-14}$ & N/A & (NASA, 2006) \\
\hline
\end{tabular}

a Where $k(\mathrm{M})=\frac{\mathrm{k}_{0}[\mathrm{M}]}{1+\frac{\mathrm{k}_{0}[\mathrm{M}]}{\mathrm{k}_{\infty}}} \times \mathrm{F}_{\mathrm{c}}$ and $\log \left(\mathrm{F}_{c}\right)=\frac{\log \left(\mathrm{F}_{\mathrm{cent}}\right)}{1+\left(\frac{\left(\log k_{0}[\mathrm{M}] k_{\infty}\right)}{\mathrm{N}}\right)^{2}}$.

$\mathrm{b}_{\alpha}$ is the branching ratio for aldehydic abstraction.

Table 2. Summary of conclusions from comparison of steady state and time dependent models.

\begin{tabular}{lllllllll}
\hline \multicolumn{3}{c}{ Upwind behavior of oVOCs } & \multicolumn{5}{c}{ Accuracy of steady state model } \\
oVOC $_{\mathrm{A}}$ & $\mathrm{oVOC}_{\mathrm{B}}$ & $\mathrm{oVOC}_{\mathrm{C}}$ & $\mathrm{APN}_{A}$ & $\mathrm{APN}_{B}$ & $\mathrm{APN}_{C}$ & $\mathrm{APN}_{A} / \mathrm{APN}_{B}$ & $\mathrm{APN}_{C} / \mathrm{APN}_{A}$ & $\mathrm{APN}_{C} / \mathrm{APN}_{B}$ \\
\hline constant & constant & constant & $\pm 10 \%$ & $\pm 10 \%$ & $\pm 10 \%$ & $\pm 10 \%$ & $\pm 10 \%$ & $\pm 10 \%$ \\
decreasing & decreasing & decreasing & $-60 \%$ & $-60 \%$ & $-60 \%$ & $\pm 15 \%$ & $\pm 25 \%$ & $\pm 25 \%$ \\
decreasing & constant & decreasing & $-60 \%$ & $\pm 10 \%$ & $-60 \%$ & $-45 \%$ & $\pm 25 \%$ & $-55 \%$ \\
\hline
\end{tabular}



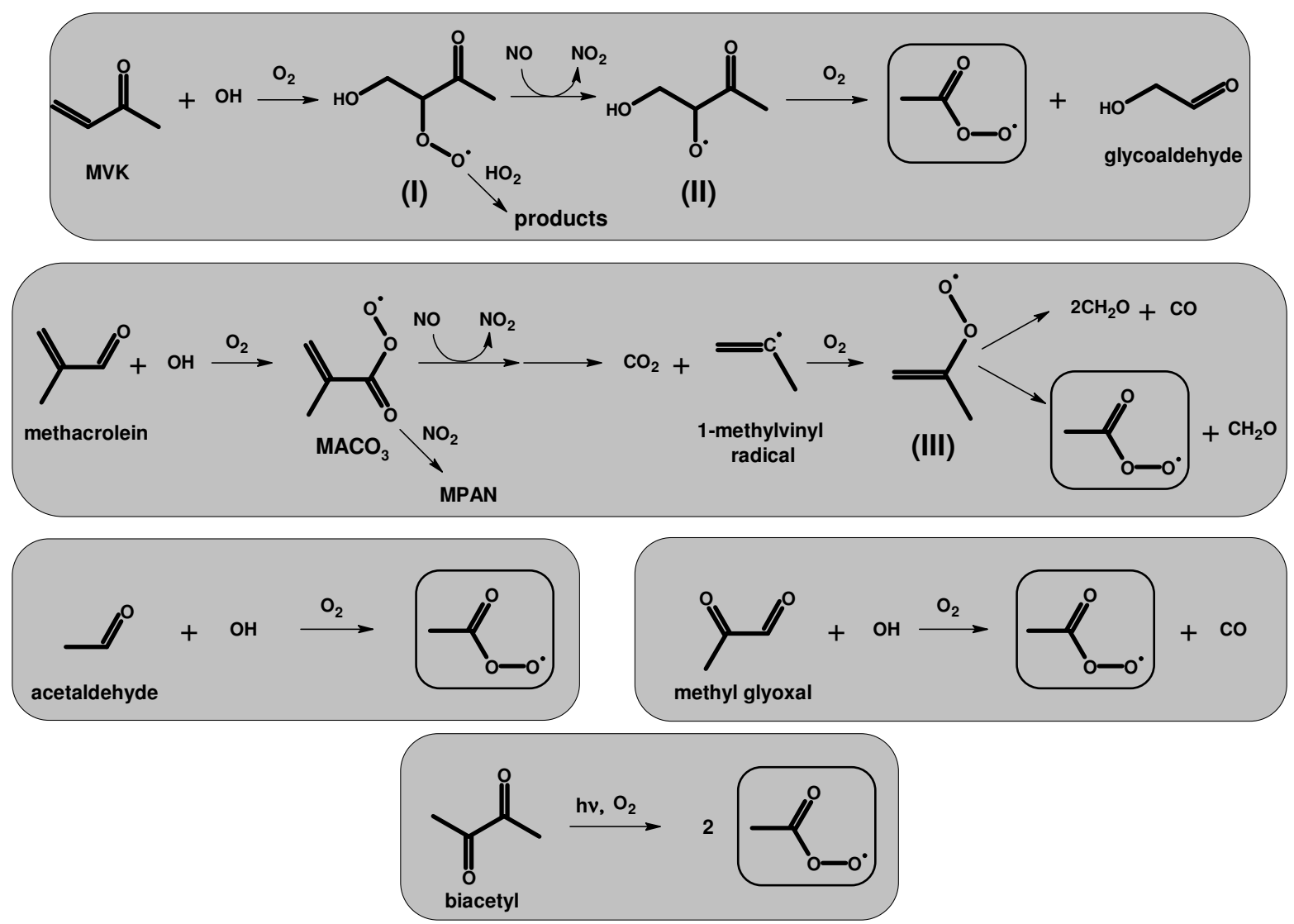

Scheme 2. Reaction mechanisms for the production of the peroxy acetyl radical (PA), which is outlined by a box in each case.

The pathways to PA radical from these five compounds are shown in Scheme 2.

The abstraction of the aldehydic $\mathrm{H}\left(\alpha_{\text {acetal }}=1\right)$ from acetaldehyde by reaction with $\mathrm{OH}$ leads to the PA radical:

$\mathrm{PA}_{\text {acetal }}=\alpha_{\text {acetal }} k_{1 \text { acetal }}[\mathrm{OH}][$ acetal $]$

Reaction of MGLY with OH (Baeza-Romero et al., 2007) occurs almost exclusively via abstraction of the aldehydic $\mathrm{H}$ $\left(\alpha_{\mathrm{mgly}}=1\right)$, and the corresponding acyl radical promptly decomposes to yield an energized acetyl radical and $\mathrm{CO}$. After relaxation, the acetyl radical reacts with $\mathrm{O}_{2}$ to form the PA radical, and $\mathrm{PA}_{\mathrm{mgly}}$ is quantified as follows:

$\mathrm{PA}_{\mathrm{mgly}}=\alpha_{\mathrm{mgly}} k_{1 \mathrm{mgly}}[\mathrm{OH}][\mathrm{MGLY}]$

We assume that the acetyl radical produced from the decomposition of the MGLY+OH reaction product gives the PA radical exclusively in the presence of $\mathrm{O}_{2}$, however, there is some evidence for a lower PA yield because the energized acetyl radical product decomposes into $\mathrm{CO}$ and $\mathrm{CH}_{3}$ at $40 \%$ yield (Baeza-Romero et al., 2007). Photolysis of MGLY can also lead to PA production, and the rate of PA production from MGLY+hv (Staffelbach et al., 1995) is expected to be similar to the actual rate of $\mathrm{OH}$ oxidation at
$[\mathrm{OH}]=5 \times 10^{6}$ molec $\mathrm{cm}^{-3}$. By neglecting MGLY $+\mathrm{h} v$ and using unity yield of PA from the MGLY reaction with $\mathrm{OH}$, we introduce compensating errors that result in a reasonable approximation of $\mathrm{PA}_{\mathrm{mgly}}$.

The PA production from MVK (Tuazon and Atkinson, 1989) starts from the reaction of $\mathrm{OH}$ with MVK at the terminal carbon of the carbon-carbon double bond at $70 \%$ yield (Tuazon and Atkinson, 1989), producing a hydroxy peroxy radical (species I, Scheme 2). Reaction of the peroxy radical with $\mathrm{NO}$ yields an alkoxy radical (species II), the $\mathrm{O}_{2}$ initiated decomposition of which produces a PA radical and glycoaldehyde, another 2nd generation isoprene oxidation product. The major competing pathway for the peroxy radical is the radical chain terminating reaction with $\mathrm{HO}_{2}$. The reaction of the MVK-derived peroxy radical with $\mathrm{RO}_{2}$ can also lead to production of species II with an estimated yield of $60 \%$ (Jenkin et al., 1997), with the remaining yield corresponding to products that are inconsequential to PA radical production. It was determined that for this analysis, this $\mathrm{RO}_{2}$ chemistry has a negligible impact on the estimated PA radical production and it is ignored here. Similarly, alkyl nitrate formation $(<10 \%$ yield) is also expected to have a negligible impact on the calculation of $\mathrm{PA}_{\mathrm{mvk}}$. Thus, the branching ratio for production of the alkoxy radical can be estimated as the 
rate of its reaction with $\mathrm{NO}$ relative to its total loss rate from reactions with $\mathrm{NO}$ and $\mathrm{HO}_{2}$. Decomposition of the alkoxy radical leads to the formation of glycoaldehyde and PA radical. The PA source from MVK is thus given by:

$$
\begin{gathered}
P A_{\mathrm{mvk}}=0.7 \times k_{1 \mathrm{mvk}}[\mathrm{OH}][\mathrm{MVK}] \\
k_{\mathrm{RO} 2+\mathrm{NO}}[\mathrm{NO}] \\
k_{\mathrm{RO} 2+\mathrm{NO}}[\mathrm{NO}]+k_{\mathrm{RO} 2+\mathrm{HO} 2}\left[\mathrm{HO}_{2}\right]
\end{gathered}
$$

The MACR pathway to the $P A$ radical (Orlando et al., 1999) proceeds through the same acyl peroxy radical that produces MPAN $\left(\mathrm{MACO}_{3}\right)$. But if the $\mathrm{MACO}_{3}$ radical reacts with $\mathrm{NO}$ instead of reacting with $\mathrm{NO}_{2}$ to form MPAN, the resulting alkoxy radical decomposes to give $\mathrm{CO}_{2}$ and the 1-methylvinyl radical (MVR). MVR quickly forms an $\mathrm{O}_{2}$ adduct (species III) which either decomposes or reacts with NO. Decomposition of the MVR-O ${ }_{2}$ adduct proceeds via two possible pathways: one forming two formaldehyde $\left(\mathrm{CH}_{2} \mathrm{O}\right)$ molecules and $\mathrm{CO}$ or one giving $\mathrm{CH}_{2} \mathrm{O}$ and the $\mathrm{PA}$ radical. The yield of the $\mathrm{CO}$ channel was determined to be $65 \%$ by Orlando et al. (1999). MVR-O $\mathrm{O}_{2}$ reaction with $\mathrm{NO}$ also leads to PA radicals and $\mathrm{CH}_{2} \mathrm{O}$. The yield for PA radical production from the MVR- $\mathrm{O}_{2}$ adduct, therefore, is taken as $35 \%$, regardless of NO concentration (Orlando et al., 1999).

The calculation of $P A_{\text {macr }}$ depends on the rate of $\mathrm{MACO}_{3}$ reaction with $\mathrm{NO}$ and the branching ratio of the MVR-O $\mathrm{O}_{2}$ adduct decomposition. The $\mathrm{MACO}_{3}$ concentration can be calculated directly from the steady-state equation (Eq. 2) for $\mathrm{AP}$ radicals. The equation for $\mathrm{PA}_{\text {macr }}$ is:

$\mathrm{PA}_{\text {macr }}=0.35 \times k_{3}\left[\mathrm{MACO}_{3}\right][\mathrm{NO}]$

Acetone is known to form PA radical through photolysis (Blitz et al., 2004), however, its lifetime of $\sim 60 \mathrm{~h}$ in the lower troposphere is too long to be relevant for the current analysis. Likewise, photolysis of MACR $(\tau \sim 50 \mathrm{~h})$ and $\operatorname{MVK}(\tau=59 \mathrm{~h})$ are also too slow (Gierczak et al., 1997) to be a significant fraction of total PA production at UC-BFRS. An additional pathway that is likely to be significant is the photolysis of biacetyl (2,3-butanedione), which leads to the production of two PA radicals as shown in Scheme 2 (Klotz et al., 2001). We use a suggested scaling factor relative to $\mathrm{J}_{\mathrm{NO} 2}(3.64 \%)$ for the biacetyl photolysis rate ( $\left.\mathrm{J}_{\text {biacet }}\right)$ (Klotz et al., 2001). PA production from biacetyl is then:

$\mathrm{PA}_{\text {biacet }}=2 \mathrm{~J}_{\text {biacet }}[$ biacetyl $]$

\subsubsection{Transport and mixing}

This analysis is greatly simplified due to the constant transport patterns between Sacramento and UC-BFRS. Both biogenic and anthropogenic species arrive at UC-BFRS from the same wind direction with regularity on a daily basis, so the simple model described in Sect. 3.2 can be reasonably applied to the current data set. A Lagrangian model has been developed for the Sacramento urban plume and tested against observations, supporting these assumptions (Dillon et al., 2002; Perez, 2008; Perez and Cohen, 2009). Further, the analysis is designed such that our assumptions about the upwind behavior of APNs, oVOCs, and oxidants can be tested using the relative behavior of MPAN and PPN, compounds for which the production rates are accurately known.

Uncertainty in the current analysis, with respect to transport and mixing, could result from different entrainment rates for the different oVOCs and APNs with background air. If, for example, the entrainment rate for $\mathrm{PAN}_{T}$ or any of its precursor oVOCs are significantly different from that for $\mathrm{MPAN}_{T}$ and $\mathrm{PPN}_{T}$ (due to different background concentrations), a situation could arise where MPAN $_{T}$ and $\mathrm{PPN}_{T}$ could be in steady-state, but not $\mathrm{PAN}_{T}$. The entrainment rates can be estimated as $-k_{\text {mix }}\left([\mathrm{X}]-[\mathrm{X}]_{\mathrm{bg}}\right)$, where $k_{\text {mix }}$ is the entrainment rate constant (determined to be $0.31 \mathrm{~h}^{-1}$ by Perez and Cohen, 2009) and [X] bg is the background concentration for a given species X. Using background concentrations estimated by Perez and Cohen (2009), the entrainment time constant is on the order of 4-5 h for $\mathrm{APN}_{T}$ and 5-10 h for the various oVOC precursors used in this analysis. The time scale for mixing, therefore, is likely too slow to be important at the highest temperatures, when chemical loss of $\operatorname{APN}_{T}(\tau<1 \mathrm{~h})$ and oVOCs $(\tau \sim 1-2 \mathrm{~h})$ are fastest. Thus, we make the assumption of equal entrainment rates and background concentrations for all APNs and oVOC precursors. Similar assumptions have been made in previous analyses of APNs (cf. Roberts et al., 2006).

\section{Observations during BEARPEX}

Average and maximum concentrations of all species used in this analysis, both measured and inferred, are listed in Table 3. Relative uncertainties for each species are also included. Values are given for the entire campaign and for the hot $\left(T>20^{\circ} \mathrm{C}\right)$ and cold $\left(T<20^{\circ} \mathrm{C}\right)$ periods of the campaign. These values are calculated only from the periods of time during which all of the relevant observations are concurrent, giving a total of 66 half-hour data points (26 during the cold period and 40 during the hot period). Over the course of the campaign, the calculated lifetimes of $\mathrm{PAN}_{T}$ and $\mathrm{PPN}_{T}$ ranged from $\sim 4 \mathrm{~h}$ at $15^{\circ} \mathrm{C}$ to $\sim 50 \mathrm{~min}$ at $30^{\circ} \mathrm{C}$, while that of MPAN $_{T}$ ranged from $\sim 2 \mathrm{~h}$ to $\sim 25 \mathrm{~min}$ at these same temperatures.

\subsection{Diurnal observations of APNs and oVOC precursors}

As a result of the extremely small day-to-day variability of horizontal transport conditions between Sacramento and the measurement site (UC-BFRS), interpretation of diurnal patterns is instructive for understanding the biogenic and anthropogenic contributions to various species. Locally emitted biogenic VOCs, for example, often follow daytime temperature and sunlight cycles coupled to boundary layer dynamics. 
Table 3. Summary of observed and inferred species for entire campaign, temperatures above $20^{\circ} \mathrm{C}$, and temperatures below $20^{\circ} \mathrm{C}$.

\begin{tabular}{|c|c|c|c|c|c|c|c|c|c|c|}
\hline \multirow[b]{2}{*}{ Species } & \multicolumn{3}{|c|}{ Full Campaign $(n=66)$} & \multicolumn{3}{|c|}{ Temperatures $>20^{\circ} \mathrm{C}(n=40)$} & \multicolumn{3}{|c|}{ Temperatures $<20^{\circ} \mathrm{C}(n=26)$} & \multirow[b]{2}{*}{ accuracy $(1 \sigma)$} \\
\hline & mean $^{\mathrm{a}}$ & median & $\max$ & mean & median & $\max$ & mean & median & $\max$ & \\
\hline PAN & 451 & 392 & 1469 & 304 & 301 & 663 & 676 & 600 & 1469 & $21 \%$ \\
\hline PPN & 43 & 29 & 160 & 20 & 18 & 51 & 77 & 79 & 160 & $21 \%$ \\
\hline MPAN & 32 & 28 & 75 & 30 & 30 & 66 & 36 & 28 & 75 & $31 \%$ \\
\hline Acetaldehyde & 589 & 538 & 1580 & 677 & 651 & 1580 & 452 & 418 & 848 & $25 \%$ \\
\hline Methyvinyl Ketone (MVK) & 1123 & 1044 & 4087 & 1741 & 1768 & 4087 & 173 & 177 & 438 & $25 \%$ \\
\hline Methacrolein (MACR) & 334 & 256 & 1107 & 480 & 484 & 1107 & 109 & 121 & 228 & $25 \%$ \\
\hline Biacetyl & 49 & 49 & 80 & 57 & 55 & 80 & 36 & 35 & 53 & $25 \%$ \\
\hline Methyl Glyoxal (MGLY) ${ }^{b}$ & 139 & 139 & 300 & 212 & 219 & 300 & 49 & 34 & 97 & $100 \%$ \\
\hline $\mathrm{NO}^{\mathrm{b}}$ & 65 & 55 & 188 & 57 & 53 & 99 & 77 & 72 & 188 & $100 \%$ \\
\hline $\mathrm{NO}_{2}^{\mathrm{c}}$ & 400 & 400 & 400 & 400 & 400 & 400 & 400 & 400 & 400 & $10 \%$ \\
\hline $\mathrm{OH}^{2}$ & 0.283 & 0.279 & 0.662 & 0.361 & 0.333 & 0.662 & 0.162 & 0.156 & 0.277 & $16 \%$ \\
\hline $\mathrm{HO}_{2}$ & 21 & 23 & 44 & 28 & 28 & 44 & 12 & 10 & 24 & $16 \%$ \\
\hline $\mathrm{RO}_{2}^{\mathrm{b}}$ & 82 & 85 & 223 & 118 & 113 & 223 & 28 & 26 & 48 & $100 \%$ \\
\hline $\mathrm{O}_{3}(\mathrm{ppbv})$ & 57 & 57 & 83 & 63 & 65 & 83 & 47 & 44 & 71 & $1 \%$ \\
\hline
\end{tabular}

${ }^{a}$ All concentration units are pptv unless otherwise noted.

${ }^{b}$ Concentrations inferred (see text) and given a conservative factor of 2 uncertainty.

c Average $\mathrm{NO}_{2}$ concentration used for entire analysis.
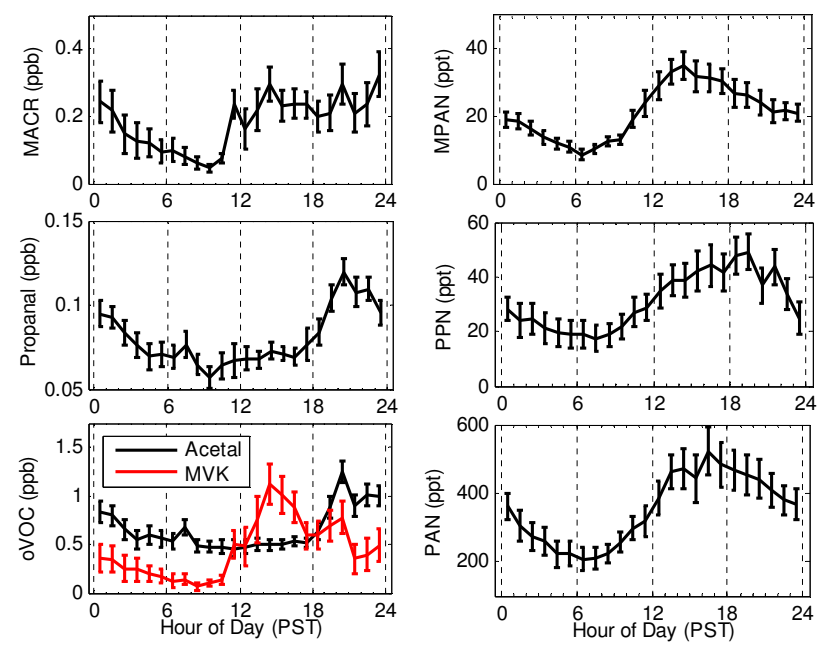

Fig. 3. Diurnal hourly medians of oVOC precursors to APNs: methacrolein, propanal, and acetaldehyde/methylvinyl ketone (acetal/MVK) (left side, top to bottom) and APNs: MPAN, PPN, and PAN (right side, top to bottom). The bars represent the $1 \sigma$ variance of the mean.

Isoprene and its oxidation products typically arrive at the site around noon, after a few hours transport from the Oak forests in the foothills. The mixing ratios of anthropogenic compounds and their oxidation products which are carried from Sacramento, further upwind, peak several hours after the arrival of the isoprene plume, typically between 18:0020:00 PST.

Average (median) diurnal concentrations of the three most abundant APNs, PAN, PPN, and MPAN, are shown in Fig. 3 (right panels) along with that of their oVOC precursors (left panels). Averages are obtained only from those times when APN and oVOC measurements were concurrent, which spanned the time period from 24 August to 27 September. The differences in the diurnal profiles of APNs can be qualitatively (and quantitatively, as we show below) explained by diurnal variations of their oVOC precursors. MPAN (Fig. 3, top right) peaks at 14:00 PST, concurrently with peak methacrolein concentrations (Fig. 3, top left), and then steadily decreases throughout the late afternoon and night. PPN (Fig. 3, middle right) rises steadily throughout the afternoon, peaking at 19:00-20:00 PST, nearly concurrently with the peak in propanal (Fig. 3, middle left). PAN (Fig. 3, bottom right) increases rapidly in the early afternoon and peaks later than the MPAN peak, but earlier than the PPN peak. This pattern is consistent with combined sources of PAN being from both biogenic and anthropogenic precursors, as shown by the diurnal profiles of MVK and acetaldehyde (Fig. 3, bottom left). Daytime (12:00-17:00 PST) average concentrations of the three APNs and their precursor oVOCs are listed in Table 3 for the full campaign as well as for the hot $\left(T>20^{\circ} \mathrm{C}\right)$ and cold periods $\left(T<20^{\circ} \mathrm{C}\right)$ of the measurement period.

\subsection{Estimated PAN production rate}

The total production rate of the $P A$ radical is given by summing Eqs. (12-16):

$$
\begin{aligned}
& \mathrm{P}\left(\mathrm{PAN}_{T}\right)=\mathrm{PA}_{\text {mvk }}+\mathrm{PA}_{\text {macr }}+\mathrm{PA}_{\text {acetal }} \\
& +\mathrm{PA}_{\text {mgly }}+\mathrm{PA}_{\text {biacet }}
\end{aligned}
$$




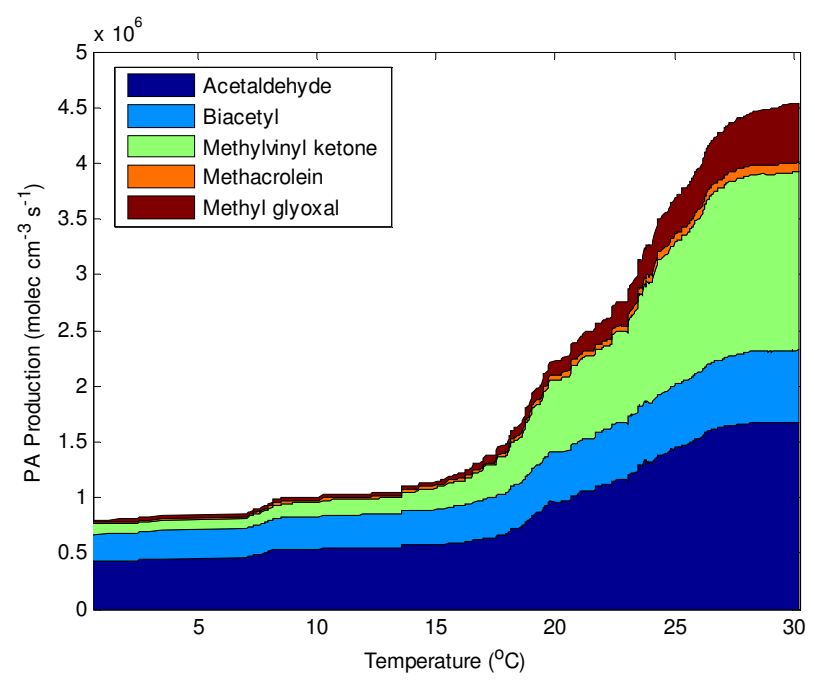

Fig. 4. Behavior of different PA production sources vs temperature. Mechanisms for each production route are shown in Scheme 2. This figure is obtained by using a running average with temperature of the calculated production rates from observations of oVOCs.

Acetaldehyde, MVK, MACR, and biacetyl were measured during BEARPEX. To calculate $\mathrm{P}\left(\mathrm{PAN}_{T}\right)$ we use an estimate of MGLY concentrations based on MGLY observations made in August and September of 2000 at UC-BFRS by Spaulding et al. (2003). Observed concentrations ranged from 32$320 \mathrm{pptv}$, with a mean of $130( \pm 60)$ pptv. In addition to isoprene, MGLY is also an oxidation product of acetone as well as a number of aromatic species (Tuazon et al., 1986; Smith et al., 1999). Spaulding et al. (2003) used factor analysis to conclude that its sources at UC-BFRS were primarily biogenic in origin. Based on this, we give our estimated MGLY mixing ratios a simple temperature dependence to simulate a biogenic source. At $15^{\circ} \mathrm{C}$ and below, we use the observed nighttime background values of $30 \mathrm{pptv}$; above $15^{\circ} \mathrm{C}$ the concentrations follow a linear relationship:

$[\mathrm{MGLY}]=30 \mathrm{pptv}+\left(\frac{270 \mathrm{pptv}}{15}\right)(T-15)$

We estimate a factor of 2 uncertainty in MGLY by this equation, resulting in variations of about $10 \%$ in the PA radical production rate $\left(\mathrm{P}\left(\mathrm{PAN}_{T}\right)\right)$.

It is instructive to view $\mathrm{P}\left(\mathrm{PAN}_{T}\right)$ and the relative strengths of each individual source as a function of temperature (Fig. 4). The data in Fig. 4 is obtained by taking a running average of the calculated production rates, using observations of oVOCs, along the temperature coordinate. The magnitude of each PA production source increases with temperature even for non-biogenic precursors as a result of the 2-3 fold increase in the observed $\mathrm{OH}$ concentrations over this temperature range. Isoprene-derived sources, particularly $\mathrm{PA}_{\mathrm{mvk}}$, increase at a still more rapid rate. $\mathrm{PA}_{\text {acetal }}$, however, decreases as a fraction of $\mathrm{P}\left(\mathrm{PAN}_{T}\right)$ from about $80 \%$ at the lowest temperatures to about $35 \%$ at the highest temperatures. At temperatures above $20^{\circ} \mathrm{C}$, methylvinyl ketone $\left(\mathrm{PA}_{\mathrm{mvk}}\right)$ becomes the dominant non-acetaldehyde source of PA radicals, reaching about $35 \%$ of the total and $60 \%$ of the non-acetaldehyde source at the highest temperatures. Methacrolein is a relatively minor source of PA radicals at UC-BFRS. $\mathrm{PA}_{\text {macr }}$ is less than $4 \%$ of $\mathrm{P}\left(\mathrm{PAN}_{T}\right)$ at any temperature. $\mathrm{PA}_{\mathrm{mgly}}$ is about $10 \%$ of the total at $30^{\circ} \mathrm{C}$. The photolytic biacetyl source shows a slight increase at high temperatures. Biacetyl concentrations remain relatively constant, but $\mathrm{PA}_{\text {biacet }}$ increases with temperature as a result of an increase in the photolysis rate on the hotter days of the campaign, which were earlier in the season and experienced slightly lower solar zenith angles. As a fraction of the total PA source, PA $_{\text {biacet }}$ decreases with increasing temperature, ranging from about $30 \%$ to about $15 \%$ of the total, at the low and high temperature limits, respectively. A summary of these results is given in Table 4, which describes averages for the entire campaign as well as those for both high $\left(>20^{\circ} \mathrm{C}\right)$ and low $\left(<20^{\circ} \mathrm{C}\right)$ temperature periods. The fractional PA production rates are given for each individual source, for the lumped non-acetaldehyde sources, and for the lumped isoprene-derived sources (MVK+MACR+MGLY). The absolute $\mathrm{PA}$ radical production rate is also given.

\section{$5 \quad \mathbf{A P N}_{T}$ ratio predictions}

As the derivation of Eqs. (6 and 7) demonstrated, APN ratios are almost exclusively sensitive to the behavior of their source oVOCs. Figure 5 shows the dependence of the ratios MPAN/PPN (Fig. 5a), MPAN/PAN (Fig. 5b), and PPN/PAN (Fig. 5b) on temperature. MPAN/PPN and MPAN/PAN ratios increase with temperature from about 0.3 to $\sim 3$ and 0.03 to 0.15 respectively. PPN/PAN, conversely, decreases with temperature from about 0.15 to 0.05 . Qualitatively, this behavior is consistent with an increase in biogenic VOCs with temperature and with MPAN being biogenic in origin, PPN being anthropogenic in origin, and PAN having some combination of both. Also shown in Fig. 5 are the predicted ratios, calculated using Eq. (6).

In order to increase the number of calculations that can be compared to the $\mathrm{APN}_{T}$ observations, a single average value of $\left[\mathrm{NO}_{2}\right]$ is used (400 pptv), while NO is allowed to vary according to the photo-stationary state equation (Eq. 10) with inputs of $\mathrm{HO}_{2}, \mathrm{RO}_{2}, \mathrm{O}_{3}$, and $\mathrm{J}_{\mathrm{NO} 2}$ in order to capture diurnal changes in the $\mathrm{NO} / \mathrm{NO}_{2}$ ratio. Our primary interest is in resolving temperature-dependent discrepancies between observations and models, which are sensitive to the $\mathrm{NO}_{2} / \mathrm{NO}$ ratio rather than the magnitude of total $\mathrm{NO}_{\mathrm{x}}$. We investigated whether diurnal changes in the absolute concentration of $\mathrm{NO}_{2}$, which has a negative correlation with temperature, are important and there was no change in our conclusions if we fix $\mathrm{NO}_{2}$ or vary its concentration with time of day based on a diurnal average. 
Table 4. Summary of PA radical sources for entire campaign, temperatures above $20^{\circ} \mathrm{C}$, and temperatures below $20^{\circ} \mathrm{C}$.

\begin{tabular}{|c|c|c|c|c|c|c|c|c|c|}
\hline \multirow[b]{2}{*}{ PA Source } & \multicolumn{3}{|c|}{ Full Campaign $\left(n^{\mathrm{a}}=66\right)$} & \multicolumn{3}{|c|}{ Temperatures $>20^{\circ} \mathrm{C}(n=40)$} & \multicolumn{3}{|c|}{ Temperatures $<20^{\circ} \mathrm{C}(n=26)$} \\
\hline & mean $(\%)$ & median $(\%)$ & $\max (\%)$ & mean $(\%)$ & median $(\%)$ & $\max (\%)$ & mean $(\%)$ & median $(\%)$ & $\max (\%)$ \\
\hline Acetaldehyde & 45.7 & 41.4 & 89.7 & 36.9 & 37.5 & 54.5 & 59.2 & 57.7 & 89.7 \\
\hline Methylvinyl Ketone (MVK) & 26.3 & 31.8 & 48.2 & 35.9 & 35.6 & 48.2 & 11.6 & 12.3 & 32.1 \\
\hline Methacrolein (MACR) & 1.9 & 1.9 & 3.8 & 1.9 & 1.9 & 3.3 & 1.8 & 1.8 & 3.8 \\
\hline Biacetyl & 19.5 & 17.4 & 56.8 & 15.4 & 13.9 & 33.1 & 25.9 & 23.9 & 56.8 \\
\hline Methyl Glyoxal (MGLY)b & 6.6 & 8.3 & 13.7 & 9.9 & 9.9 & 13.7 & 1.6 & 1.6 & 5.7 \\
\hline Total non-acetaldehyde & 54.3 & 58.6 & 80.7 & 63.1 & 62.5 & 80.7 & 40.8 & 42.3 & 69.7 \\
\hline Total isoprene-derived ${ }^{\mathrm{c}}$ & 34.8 & 40.7 & 63.7 & 47.7 & 48.1 & 63.7 & 14.9 & 16.2 & 39.0 \\
\hline Total PA Production Rate ${ }^{\mathrm{d}}$ & $3.0 \times 10^{6}$ & $2.6 \times 10^{6}$ & $1.2 \times 10^{7}$ & $4.4 \times 10^{6}$ & $4.2 \times 10^{6}$ & $1.2 \times 10^{7}$ & $1.0 \times 10^{6}$ & $9.1 \times 10^{5}$ & $2.4 \times 10^{6}$ \\
\hline
\end{tabular}

a $n$ represents the number of 30 min averaged observations for each time period.

${ }^{b}$ MGLY concentrations estimated from Spaulding et al. (2003) according to Eq. (20).

${ }^{c}$ Isoprene-derived sources include MVK, MACR, and MGLY.

${ }^{d}$ Production rate given in units of molecules $\mathrm{cm}^{-3} \mathrm{~s}^{-1}$.

The uncertainty in the calculated $\mathrm{APN}_{T}$ ratios is estimated to be $\sim 40 \%$ based on propagation of the uncertainties in the individual observations used in Eq. (6), a similar or larger value to the accuracy expected based on approximations used to derive the equation. The experimental uncertainty stems mainly from the uncertainty in absolute concentrations of calibration standards, and thus does not have any temperature dependence. As the $\mathrm{APN}_{T}$ ratios are mainly a function of the ratios of their production rates, uncertainty in our inferred concentrations of $\mathrm{NO}$ and $\mathrm{RO}_{2}$ has only a minor effect on the $\mathrm{APN}_{T}$ ratio calculations. A factor of 2 uncertainty in both $\mathrm{NO}$ and $\mathrm{RO}_{2}$ results in only a $5 \%$ increase in the $\mathrm{APN}_{T}$ ratio uncertainty.

Panels a-b in Fig. 5 show that the predicted ratios exhibit the same general behavior as the observations for all three $\mathrm{APN}_{T}$ pairs. Figure 6 shows the comparison between observed and predicted $\mathrm{APN}_{T}$ ratios along the temperature coordinate. A value of 1 in this plot corresponds to perfect agreement between observations and predictions. All data points in this figure are the averages of between 5 and 8 individual half-hour measurement-model pairs. The bars represent the $1 \sigma$ variance of the mean for each bin. As discussed previously, the accuracy in predicting relative $\mathrm{APN}_{T}$ concentrations with the steady-state equation relies on the oVOC precursors for both APNs having similar sources and sinks, such that there are slow (relative to the $\mathrm{APN}_{T}$ lifetime) upwind changes in the oVOC ratio. The main driver of differences in oVOC behavior along the Sacramento-UCBFRS transect is the relative importance of anthropogenic versus biogenic, and primary versus secondary sources of the oVOCs. Smaller differences arise from the different lifetimes of the oVOC precursors. The emission sources of the anthropogenic parent compounds to propanal and acetaldehyde are negligible immediately outside of Greater Sacramento (Dillon et al., 2002; Murphy et al., 2006, 2007), while the emission sources of isoprene, the parent compound to both
MVK and MACR, maximize about an hour or so downwind of Greater Sacramento. In the immediate upwind vicinity of UC-BFRS, therefore, propanal and acetaldehyde are more likely to be following an exponential decay, while changes in MACR and MVK are more likely affected to some extent by local production. A useful strategy for estimating the upwind behavior of oVOCs is to calculate the instantaneous loss and production rates at UC-BFRS for each oVOC. Using observations of isoprene and $\mathrm{OH}$ at UC-BFRS, we find that the production rate of MVK and MACR exceeds their chemical loss rates at high temperatures by as much as a factor of 1.6 and 2.3, respectively. Production rates calculated for propanal from observations of n-propanol, and for acetaldehyde from observations of ethanol, are estimated to be only about $10 \%$ and $50 \%$, respectively, of their loss rates to $\mathrm{OH}$. In addition to chemical production, however, local emissions are likely to be an additional source of acetaldehyde at UCBFRS (Schade and Goldstein, 2001). At an estimated flux of $0.2 \mathrm{mg} \mathrm{C} \mathrm{m}^{-2} \mathrm{~h}^{-1}$ at $30^{\circ} \mathrm{C}$ (Schade and Goldstein, 2001), emissions of acetaldehyde correspond to an atmospheric production rate similar to that expected from ethanol oxidation. Thus, acetaldehyde loss is calculated to be equal to the sum of chemical production and local emissions, with the effect that acetaldehyde is approximately in steady-state at a constant value upwind of UC-BFRS.

The predictions and observations of all three $\mathrm{APN}_{T}$ ratios are in agreement to better than $40 \%$ at temperatures above $27^{\circ} \mathrm{C}$ and within $25 \%$ at the highest temperature. Deviations of the steady-state predictions from observations at low temperatures can be explained by significant differences in the loss rates for MPAN ${ }_{T}$ relative to $\mathrm{PPN}_{T}$ and $\mathrm{PAN}_{T}$ as a result of its fast loss to $\mathrm{OH}$, which are especially apparent at low temperatures where loss to thermal decomposition for APNs is slow. Under these conditions, the steady-state Eq. (7) will not approximate the time-dependent Eq. (9). For the conditions observed during BEARPEX, Reaction (R6) becomes 
(a)

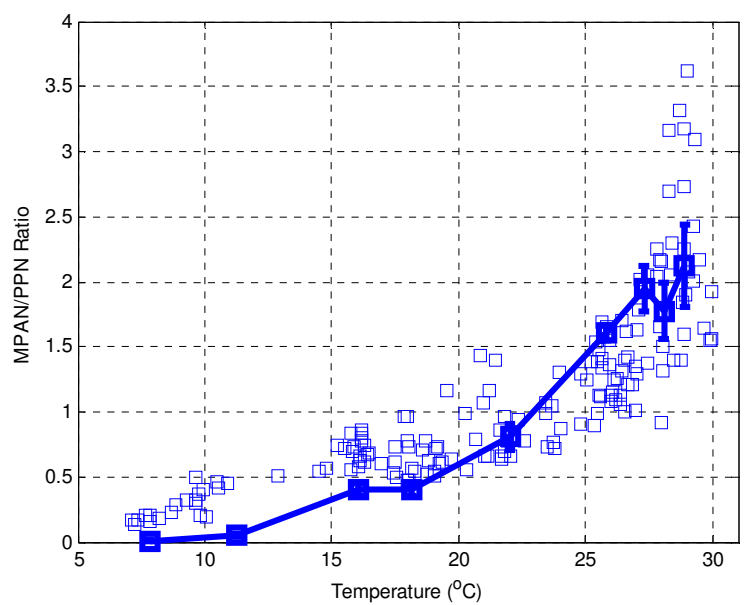

(b)

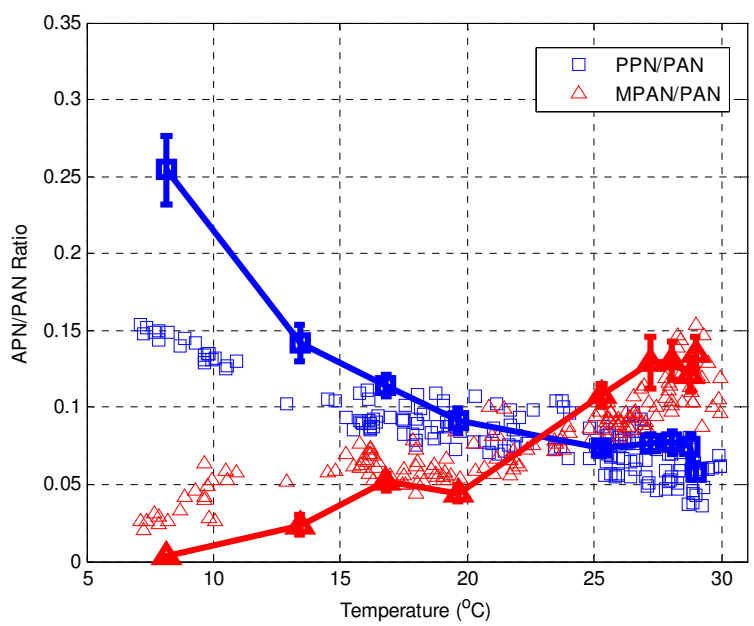

Fig. 5. Observed APN ratios vs. temperature: (a) MPAN/PPN (blue squares) and (b) MPAN/PAN (red triangles) and PPN/PAN (blue squares). Also shown are the steady-state predictions for each ratio, binned by temperature (connected symbols); the bars represent the $1 \sigma$ variance of the predicted mean

the dominant loss pathway for $\operatorname{MPAN}_{T}$ when temperatures are below $24^{\circ} \mathrm{C}$. At $30^{\circ} \mathrm{C}$, Reaction (R6) accounts for about $40 \%$ of the total loss of MPAN $_{T}$. Therefore, the ratios involving MPAN are significantly underestimated as temperatures get colder. Similarly, since the thermal decomposition lifetime of PPN is about 30\% lower than that of PAN at the lowest temperatures, the $\mathrm{PPN}_{T} / \mathrm{PAN}_{T}$ ratio is significantly overestimated at these temperatures.

The uncertainty in the absolute PA radical production rate is estimated to be about $20-30 \%$. Individual contributions to this uncertainty are largest for the MVK $(10 \%)$ and acetaldehyde $(9 \%)$ sources. Propagating this uncertainty through the calculation of the $\mathrm{MPAN}_{T} / \mathrm{PAN}_{T}$ and $\mathrm{PPN}_{T} / \mathrm{PAN}_{T}$ ratios

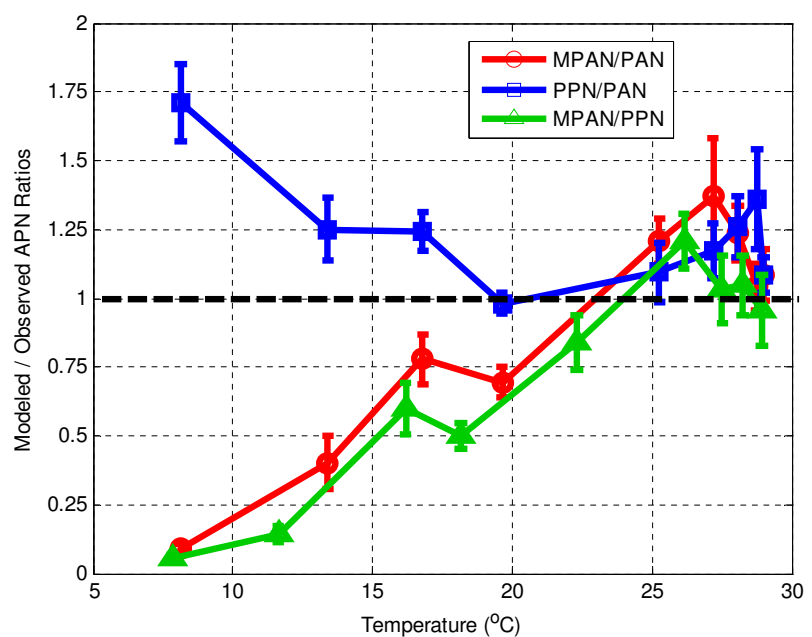

Fig. 6. Modeled-to-observed ratios for: PPN/PAN ratio (blue squares), MPAN/PAN ratio (red circles), and MPAN/PPN (green triangles). The bars represent the $1 \sigma$ variance of the mean.

(Eq. 7) gives an overall uncertainty of $40 \%$ in the predicted $\mathrm{APN}_{T}$ ratios. Therefore, the agreement between predictions and observations, within this uncertainty, of the $\mathrm{MPAN}_{T} / \mathrm{PAN}_{T}$ and $\mathrm{PPN}_{T} / \mathrm{PAN}_{T}$ ratios at the highest temperatures is evidence that our parameterization of PA radical production is accurate. Alternatively, it is possible that we have underestimated the production of all 3 AP radicals equally, but we dismiss this as unlikely. We estimate, therefore, based on the total uncertainty in the steady-state approximation (see Sect. 3.2), that the PA radical budget is closed to within $40 \%$. To our knowledge, this is the first experimental study where explicit bottom-up analysis of the PA radical budget has achieved closure.

\section{Absolute APN concentrations}

In Sect. 5 we used APN ratios to constrain their production rates. Here we take those production rates as known values and evaluate our understanding of APN loss rates using absolute APN concentrations. Figure 7 shows the steady-state concentrations for PAN, MPAN, and PPN (Eq. 5) divided by the observations as a function of temperature. As in Fig. 6, all observations in this figure are the averages of between 5 and 8 individual half-hour measurement-model pairs, with bars representing the $1 \sigma$ variance of the mean. As shown in Fig. 7, the modeled-to-observed ratios for all three APNs are significantly different from 1 at temperatures below $15^{\circ} \mathrm{C}$. This disagreement is expected for all three APNs: both the long $\mathrm{APN}_{T}$ lifetimes at low temperatures and the dependence of the steady-state predictions on changes in absolute oVOC concentrations over this lifetime contribute to these differences. The model prediction of excess PAN and PPN implies that the rate of change in the production term exceeds the 
$\mathrm{APN}_{T}$ loss rate (i.e. the exponential term in Eq. 5 is positive) at low temperature. Conversely, the prediction of too little MPAN implies that its loss rate remains fast enough (due to its reaction with $\mathrm{OH}$ ) that it exceeds the rate of change in oVOC precursor (MACR) concentrations (i.e. the exponential term in Eq. 5 is negative).

The model agrees with observations for PAN to within $25 \%$, for PPN to within $50 \%$, and for MPAN to within $35 \%$ between $15^{\circ} \mathrm{C}$ and $20^{\circ} \mathrm{C}$. Above $20^{\circ} \mathrm{C}$, all three APNs are increasingly over-estimated by the model. The model for all three APNs predicts $60-100 \%$ more than is observed at temperatures greater than $27^{\circ} \mathrm{C}$. This result is surprising since deviations from steady-state should approach zero (modeled-to-observed ratio $=1$ ) as temperatures rise and $\mathrm{APN}_{T}$ lifetimes decrease. While deposition is not considered in our steady-state model, its inclusion decreases the predicted APN concentrations only by $\sim 5 \%$ at high temperatures using the highest deposition velocity $\left(1.3 \mathrm{~cm} \mathrm{~s}^{-1}\right)$ reported by Wolfe et al. (2009). Additionally, the assumption that $[\mathrm{APN}] \approx\left[\mathrm{APN}_{T}\right]$ is valid since we calculate that $\mathrm{AP}$ radical concentrations are less than $3 \%$ of their corresponding APN over the entire campaign.

We suspect that the chemical model used to describe APN concentrations is missing a significant reactive loss channel for AP radicals. It is unknown whether this is a result of an error in our estimation of the $\mathrm{NO}, \mathrm{HO}_{2}$, or $\mathrm{RO}_{2}$ loss rates or a result of neglecting some additional loss term, such as photolysis or aerosol uptake. An error in the inferred [NO], based on the $\mathrm{NO}-\mathrm{NO}_{2}-\mathrm{O}_{3}$ photostationary-state assumptions is possible, however, previous measurements of $\mathrm{NO}$ and $\mathrm{NO}_{2}$ at UC-BFRS indicate that a factor of 3 error in the $\mathrm{NO} / \mathrm{NO}_{2}$ ratio, required to force agreement between the APN model and observations, is unlikely at this particular site, which is far removed from significant $\mathrm{NO}_{\mathrm{x}}$ sources (Day et al., 2009). A significant uncertainty in the model is in the estimate of the $\mathrm{AP}+\mathrm{RO}_{2}$ reaction rate, stemming from an uncertainty in the estimated concentrations of $\mathrm{RO}_{2}$ (from Eq. 10) and in the reaction rate constant $\left(k_{5}\right)$. We estimate that the average $\mathrm{RO}_{2} / \mathrm{HO}_{2}$ ratio is about 4 , and at high temperatures, $\mathrm{RO}_{2}$ can contribute to as much as $35 \%$ of the total AP radical loss. The rate constant used in our analysis for these reactions is that reported for the reaction of the PA radical with the methyl peroxy radical $\left(\mathrm{CH}_{3} \mathrm{O}_{2}\right)$. Villenave et al. (1998) have suggested, based on experimental and theoretical considerations, that reactions of acyl peroxy radicals with any peroxy radical will proceed at a rate similar to that of $\mathrm{PA}+\mathrm{CH}_{3} \mathrm{O}_{2}$, regardless of the size or functionality of the organic chains. The reactions of acyl peroxy radicals with hydroxy-functionalized $\mathrm{RO}_{2}$ radicals were not specifically considered by Villenave et al. (1998), nor have they been investigated in any other experimental study, to our knowledge. This is important as the majority of peroxy radicals at UC-BFRS during the afternoon are hydroxy-peroxy radicals derived from 2-methylbut3-en-2-ol (MBO), isoprene, terpenes, and their respective oxidation products. An increase in the rate constant for AP

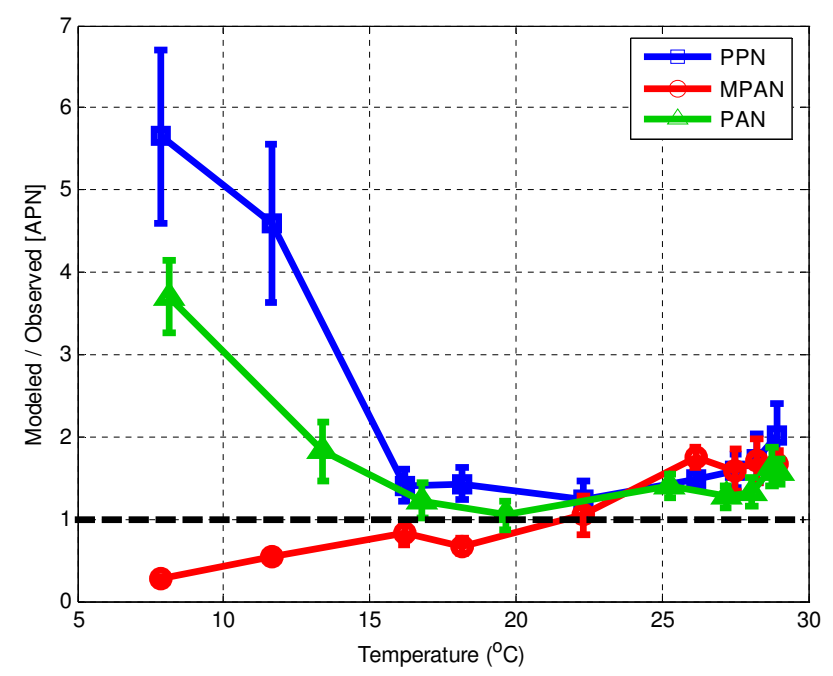

Fig. 7. Modeled-to-observed ratios for: PAN (green triangles), PPN (blue squares), and MPAN (red circles). The bars represent the $1 \sigma$ variance of the mean.

radicals reacting with the pool of $\mathrm{RO}_{2}$ radicals by a factor of 3 would bring the predicted APN concentrations into agreement with observations at the highest temperatures. For comparison, the $\mathrm{RC}(\mathrm{O}) \mathrm{O}_{2}+\mathrm{HO}_{2}$ rate constant is about a factor of 1.5 higher than the $\mathrm{RC}(\mathrm{O}) \mathrm{O}_{2}+\mathrm{RO}_{2}$ rate constant.

An increase in the calculated $\mathrm{RO}_{2}$ concentrations would also help explain the model bias and may be a more likely possibility since a significant increase in $k_{5}$ would lead to a lower estimate of $\left[\mathrm{RO}_{2}\right]$ via Eq. (10), since the effective $k_{\mathrm{RO} 2+\mathrm{RO} 2}$ rate constant would increase. The $\mathrm{RO}_{2}$ production term in Eq. (10) neglects direct production from carbonyl photolysis, alkene ozonolysis, and decomposition of alkoxy radicals, which may be important at UC-BFRS. Without running a detailed chemical model, which is beyond the scope of this study, it is difficult to make a better approximation for $\mathrm{RO}_{2}$. Our estimates are, however, consistent with those resulting from an analysis of the $\mathrm{NO}-\mathrm{NO}_{2}-\mathrm{O}_{3}$ photo-stationary state at UC-BFRS in 2001 (Day et al., 2009). While it seems unlikely that $\mathrm{RO}_{2}$ is under estimated by a factor of 3 , there is some precedent in the literature for higher observed $\mathrm{RO}_{2} / \mathrm{HO}_{2}$ ratios than our estimation during BEARPEX (Mihelcic et al., 2003; Emmerson et al., 2007).

While we believe that chemical loss of AP radicals is the most likely source of error in the model, there are other possibilities that may contribute to the observation-model differences.

We have also considered, for example, the likelihood that fast spatio-temporal variations in APN sources or sinks may be responsible for driving APNs out of steady-state. The changes required in [oVOC], $\beta$, and/or $[\mathrm{OH}]$ over the 5$10 \mathrm{~km}$ upwind of UC-BFRS are too fast to be realistic based on previous work modeling the Sacramento-UC-BFRS transect (Perez, 2008; Perez and Cohen, 2009). 


\section{Conclusions}

We have presented an observationally constrained steadystate analysis of PAN, PPN, and MPAN. We estimate a total non-acetaldehyde source of peroxy acetyl radicals (PA), and thus PAN, that is up to $\sim 4$ times that of acetaldehyde and find that methylvinyl ketone, methyl glyoxal, biacetyl, and methacrolein represent $63 \%$ of the total PA radical source on average at the highest observed temperatures. This is the first time that observations have confirmed the The magnitude of the inferred non-acetaldehyde PA radical source is similar to that reported as an unexplained PA radical source in other biogenically influenced observations, typically in the range of 2-3 times that of the acetaldehyde source (Roberts et al., 2001, 2006; Cleary et al., 2007). During BEARPEX 2007, values ranged from $\sim 0.5$ to $\sim 4$ times the calculated production from acetaldehyde and were about 1.7 times that of acetaldehyde on average at temperatures greater than $20^{\circ} \mathrm{C}$. Methylvinyl ketone, an isoprene oxidation product, explains, on average, $35 \%$ of the non-acetaldehyde source when temperatures exceeded $20^{\circ} \mathrm{C}$. Biacetyl can contribute $15 \%$ the total PA production under high temperature conditions, but it is most important in a relative sense when isoprene-derived sources are low. At temperatures below $20^{\circ} \mathrm{C}$, acetaldehyde contributes $\sim 60 \%$ and biacetyl accounts for $\sim 25 \%$ of the total PA radical sources.

We find that the MPAN/PAN and PPN/PAN ratios can be described by a steady-state model to within $40 \%$ at temperatures greater than $15^{\circ} \mathrm{C}$, thus verifying the proposed mechanisms for PA radical production. Predictions for the MPAN/PPN ratio are within $40 \%$ of observations at temperatures above $27^{\circ} \mathrm{C}$. Absolute concentrations of PAN, PPN, and MPAN are all predicted to be too high by a factor of 1.6-2 at the highest observed temperatures, indicating some common bias in the steady-state model for absolute APN concentrations. We suggest that experiments aimed at measuring the rate constants of the PA radical with a series of hydroxy peroxy radicals are needed to constrain the loss rates of APNs in low $\mathrm{NO}_{\mathrm{x}} /$ high $\mathrm{VOC}$ regimes.

Acknowledgements. The authors thank the UC Blodgett Forest Research Station staff for logistical support and Sierra Pacific Industries for access to their land. This work was supported by the National Science Foundation (grants ATM-0639847 (Berkeley) and ATM-0633897 (UW)). B. LaFranchi acknowledges support from the Camille and Henry Dreyfus Postdoctoral Program in Environmental Chemistry. G. Wolfe acknowledges support from NASA ESSF NNG-05GP64H.

Edited by: J. Lelieveld

\section{References}

Atkinson, R., Baulch, D. L., Cox, R. A., Hampson, R. F., Kerr, J. A., Rossi, M. J. and Troe, J.: Evaluated kinetic and photochemical data for atmospheric chemistry: Supplement VI - IUPAC subcommittee on gas kinetic data evaluation for atmospheric chemistry, J. Phys. Chem. Ref. Data, 26, 1329-1499, 1997.

Atkinson, R., Baulch, D. L., Cox, R. A., Crowley, J. N., Hampson, R. F., Hynes, R. G., Jenkin, M. E., Rossi, M. J., and Troe, J.: Evaluated kinetic and photochemical data for atmospheric chemistry: Volume $\mathrm{I}$ - gas phase reactions of $\mathrm{O}_{\mathrm{x}}, \mathrm{HO}_{\mathrm{x}}, \mathrm{NO}_{\mathrm{x}}$ and $\mathrm{SO}_{\mathrm{x}}$ species, Atmos. Chem. Phys., 4, 1461-1738, 2004, http://www.atmos-chem-phys.net/4/1461/2004/.

Atkinson, R., Baulch, D. L., Cox, R. A., Crowley, J. N., Hampson, R. F., Hynes, R. G., Jenkin, M. E., Rossi, M. J., Troe, J., and IUPAC Subcommittee: Evaluated kinetic and photochemical data for atmospheric chemistry: Volume II - gas phase reactions of organic species, Atmos. Chem. Phys., 6, 3625-4055, 2006, http://www.atmos-chem-phys.net/6/3625/2006/.

Baeza-Romero, M. T., Glowacki, D. R., Blitz, M. A., Heard, D. E., Pilling, M. J., Rickard, A. R., and Seakins, P. W.: A combined experimental and theoretical study of the reaction between methylglyoxal and OH/OD radical: OH regeneration, Phys. Chem. Chem. Phys., 9, 4114-4128, 2007.

Bertman, S. B. and Roberts, J. M.: A PAN analogue from isoprene photooxidation, Geophys. Res. Lett., 18, 1461-1464, 2001.

Blitz, M. A., Heard, D. E., Pilling, M. J., Arnold, S. R. and Chipperfield, M. P.: Pressure and temperature-dependent quantum yields for the photodissociation of acetone between 279 and $327.5 \mathrm{~nm}$, Geophys. Res. Lett., 31, L09104, doi:10.1029/2004GL020182, 2004.

Bouvier-Brown, N. C., Goldstein, A. H., Worton, D. R., Matross, D. M., Gilman, J. B., Kuster, W. C., Welsh-Bon, D., Warneke, C., de Gouw, J. A., Cahill, T. M., and Holzinger, R.: Methyl chavicol: characterization of its biogenic emission rate, abundance, and oxidation products in the atmosphere, Atmos. Chem. Phys. Discuss., 8, 19707-19741, 2008,

http://www.atmos-chem-phys-discuss.net/8/19707/2008/.

Bytnerowicz, A. and Fenn, M. E.: Nitrogen deposition in California forests: A review, Environ. Pollut., 92, 127-146, 1996.

Cahill, T. M., Seaman, V. Y., Charles, M. J., Holzinger, R., and Goldstein, A. H.: Secondary organic aerosols formed from oxidation of biogenic volatile organic compounds in the Sierra Nevada Mountains of California, J. Geophys. Res., 111, D16312, doi:10.1029/2006JD007178, 2006.

Carter, W. P. L. and Atkinson, R.: Atmospheric Chemistry of Alkanes, J. Atmos. Chem., 3, 377-405, 1985.

Carter, W. P. L.: A Detailed Mechanism for the Gas-Phase Atmospheric Reactions of Organic-Compounds, Atmos. Environ. AGen., 24, 481-518, 1990.

Cleary, P. A., Wooldridge, P. J., Millet, D. B., McKay, M., Goldstein, A. H., and Cohen, R. C.: Observations of total peroxy nitrates and aldehydes: measurement interpretation and inference of OH radical concentrations, Atmos. Chem. Phys., 7, 19471960, 2007, http://www.atmos-chem-phys.net/7/1947/2007/.

Cohen, R. C. and Goldstein, A. H.: Observations in the Foothills of the Sierra Nevada Mountains: A review motivating the Biosphere Effects on AeRosols and Photochemistry Experiment (BEARPEX), Atmos. Chem. Phys. Discuss., in preparation, 2009. 
Day, D. A., Wooldridge, P. J., and Cohen, R. C.: Observations of the effects of temperature on atmospheric $\mathrm{HNO}_{3}, \Sigma \mathrm{ANs}, \Sigma \mathrm{PNs}$, and $\mathrm{NO}_{\mathrm{x}}$ : evidence for a temperature-dependent $\mathrm{HO}_{\mathrm{x}}$ source, Atmos. Chem. Phys., 8, 1867-1879, 2008,

http://www.atmos-chem-phys.net/8/1867/2008/.

Day, D. A., Farmer, D. K., Goldstein, A. H., Wooldridge, P. J., Minejima, C., and Cohen, R. C.: Observations of $\mathrm{NO}_{\mathrm{x}}, \Sigma \mathrm{PNs}$, $\Sigma$ ANs, and $\mathrm{HNO}_{3}$ at a Rural Site in the California Sierra Nevada Mountains: summertime diurnal cycles, Atmos. Chem. Phys., 9, 4879-4896, 2009,

http://www.atmos-chem-phys.net/9/4879/2009/.

Dillon, M., Lamanna, M., Schade, G., Goldstein, A., and Cohen, R.: Chemical evolution of the Sacramento urban plume: Transport and oxidation, J. Geophys. Res., 107, 4046, doi:10.1029/2001JD000969, 2002.

Dreyfus, G. B., Schade, G. W., and Goldstein, A. H.: Observational constraints on the contribution of isoprene oxidation to ozone production on the western slope of the Sierra Nevada, California, J. Geophys. Res., 107, 4365, doi:10.1029/2001JD001490, 2002.

Emmerson, K. M., Carslaw, N., Carslaw, D. C., Lee, J. D., McFiggans, G., Bloss, W. J., Gravestock, T., Heard, D. E., Hopkins, J., Ingham, T., Pilling, M. J., Smith, S. C., Jacob, M., and Monks, P. S.: Free radical modelling studies during the UK TORCH Campaign in Summer 2003, Atmos. Chem. Phys., 7, 167-181, 2007, http://www.atmos-chem-phys.net/7/167/2007/.

Faloona, I. C., Tan, D., Lesher, R. L., Hazen, N. L., Frame, C. L., Simpas, J. B., Harder, H., Martinez, M., Di Carlo, P., Ren, X. R., and Brune, W. H.: A laser-induced fluorescence instrument for detecting tropospheric $\mathrm{OH}$ and $\mathrm{HO}_{2}$ : Characteristics and calibration, J. Atmos. Chem., 47, 139-167, 2004.

Farmer, D. K., Wooldridge, P. J., and Cohen, R. C.: Application of thermal-dissociation laser induced fluorescence (TD-LIF) to measurement of $\mathrm{HNO}_{3}$, Salkyl nitrates, $\Sigma$ peroxy nitrates, and $\mathrm{NO}_{2}$ fluxes using eddy covariance, Atmos. Chem. Phys., 6, 3471-3486, 2006,

http://www.atmos-chem-phys.net/6/3471/2006/.

Farmer, D. K. and Cohen, R. C.: Observations of $\mathrm{HNO}_{3}, \Sigma \mathrm{AN}$, $\Sigma \mathrm{PN}$ and $\mathrm{NO}_{2}$ fluxes: evidence for rapid $\mathrm{HO}_{\mathrm{x}}$ chemistry within a pine forest canopy, Atmos. Chem. Phys., 8, 3899-3917, 2008, http://www.atmos-chem-phys.net/8/3899/2008/.

Farmer, D. K., Cohen, R. C., Perring, A. E., Wooldridge, P. J., Blake, D., Baker, A., Huey, L. G., Sjostedt, S., Tanner, D., Vargas, O., de Gouw, J., Warneke, C., Kuster, W. and Murphy, J. G.: $\mathrm{NO}_{\mathrm{y}}$ partitioning and the role of alkyl nitrates in air quality in the Mexico City Area, Atmos. Chem. Phys. Discuss., in preparation, 2009.

Folberth, G. A., Hauglustaine, D. A., Lathière, J., and Brocheton, F.: Interactive chemistry in the Laboratoire de Météorologie Dynamique general circulation model: model description and impact analysis of biogenic hydrocarbons on tropospheric chemistry, Atmos. Chem. Phys., 6, 2273-2319, 2006,

http://www.atmos-chem-phys.net/6/2273/2006/.

Fuchs, H., Brown, S. S., Dube, W., et al.: Intercomparison of instruments measuring $\mathrm{NO}_{2}$ at the atmosphere simulation chamber SAPHIR, Atmos. Chem. Phys. Discuss., in preparation, 2009.

Gierczak, T., Burkholder, J. B., Talukdar, R. K., Mellouki, A., Barone, S. B., and Ravishankara, A. R.: Atmospheric fate of methyl vinyl ketone and methacrolein, J. Photoch. Photobio. A, 110, 1-10, 1997.
Goldan, P. D., Kuster, W. C., Williams, E., Murphy, P. C., Fehsenfeld, F. C., and Meagher, J.: Nonmethane hydrocarbon and oxy hydrocarbon measurements during the 2002 New England Air Quality Study, J. Geophys. Res., 109, D21309, doi:10.1029/2003JD004455, 2004.

Goldstein, A., Hultman, N., Fracheboud, J., Bauer, M., Panek, J., Xu, M., Qi, Y., Guenther, A. and Baugh, W.: Effects of climate variability on the carbon dioxide, water, and sensible heat fluxes above a ponderosa pine plantation in the Sierra Nevada (CA), Agr. Forest Meteorol., 101, 113-129, 2000.

Goulding, K. W. T., Bailey, N. J., Bradbury, N. J., Hargreaves, P., Howe, M., Murphy, D. V., Poulton, P. R., and Willison, T. W.: Nitrogen deposition and its contribution to nitrogen cycling and associated soil processes, New Phytol., 139, 49-58, 1998.

Grosjean, E., Grosjean, D., Woodhouse, L. F., and Yang, Y. J.: Peroxyacetyl nitrate and peroxypropionyl nitrate in Porto Alegre, Brazil, Atmos. Environ., 36, 2405-2419, 2002.

Holzinger, R., Lee, A., Paw, K. T., and Goldstein, U. A. H.: Observations of oxidation products above a forest imply biogenic emissions of very reactive compounds, Atmos. Chem. Phys., 5, 67-75, 2005, http://www.atmos-chem-phys.net/5/67/2005/.

Horowitz, L. W., Liang, J. Y., Gardner, G. M., and Jacob, D. J.: Export of reactive nitrogen from North America during summertime: Sensitivity to hydrocarbon chemistry, J. Geophys. Res., 103, 13451-13476, 1998.

Hudman, R. C., Jacob, D. J., Cooper, O. R., Evans, M. J., Heald, C. L., Park, R. J., Fehsenfeld, F., Flocke, F., Holloway, J., Hubler, G., Kita, K., Koike, M., Kondo, Y., Neuman, A., Nowak, J., Oltmans, S., Parrish, D., Roberts, J. M., and Ryerson, T.: Ozone production in transpacific Asian pollution plumes and implications for ozone air quality in California, J. Geophys. Res., 109, D23S10, doi:10.1029/2004JD004974, 2004.

Jenkin, M. E., Saunders, S. M., and Pilling, M. J.: The tropospheric degradation of volatile organic compounds: A protocol for mechanism development, Atmos. Environ., 31, 81-104, 1997.

Kirchner, F., Mayer-Figge, A., Zabel, F., and Becker, K. H.: Thermal stability of peroxynitrates, Int. J. Chem. Kinet., 31, 127-144, 1999.

Klotz, B., Graedler, F., Sorensen, S., Barnes, I., and Becker, K. H.: A kinetic study of the atmospheric photolysis of alphadicarbonyls, Int. J. Chem. Kinet., 33, 9-20, 2001.

Kotchenruther, R. A., Jaffe, D. A., and Jaegle, L.: Ozone photochemistry and the role of peroxyacetyl nitrate in the springtime northeastern Pacific troposphere: Results from the Photochemical Ozone Budget of the Eastern North Pacific Atmosphere (PHOBEA) campaign, J. Geophys. Res., 106, 2873128742, 2001.

Kurpius, M. R. and Goldstein, A. H.: Gas-phase chemistry dominates $\mathrm{O}_{3}$ loss to a forest, implying a source of aerosols and hydroxyl radicals to the atmosphere, Geophys. Res. Lett., 30, 1371, doi:10.1029/2002GL016785, 2003.

Lamanna, M. and Goldstein, A.: In situ measurements of C-2-C10 volatile organic compounds above a Sierra Nevada ponderosa pine plantation, J. Geophys. Res., 104, 21247-21262, 1999.

Lei, W., de Foy, B., Zavala, M., Volkamer, R., and Molina, L. T.: Characterizing ozone production in the Mexico City Metropoli$\tan$ Area: a case study using a chemical transport model, Atmos. Chem. Phys., 7, 1347-1366, 2007,

http://www.atmos-chem-phys.net/7/1347/2007/. 
Madronich, S.: Photodissociation in the Atmosphere, 1, Actinic Flux and the Effects of Ground Reflections and Clouds, J. Geophys. Res., 92, 9740-9752, 1987.

Magnani, F., Mencuccini, M., Borghetti, M., Berbigier, P., Berninger, F., Delzon, S., Grelle, A., Hari, P., Jarvis, P. G., Kolari, P., Kowalski, A. S., Lankreijer, H., Law, B. E., Lindroth, A., Loustau, D., Manca, G., Moncrieff, J. B., Rayment, M., Tedeschi, V., Valentini, R., and Grace, J.: The human footprint in the carbon cycle of temperate and boreal forests, Nature, 447, 848-850, 2007.

MCM, Master Chemical Mechansim (MCM 3.1), http://www. chem.leeds.ac.uk/Atmospheric/MCM/mcmproj.html, last access: 16 March 2009, 2003.

Mihelcic, D., Holland, F., Hofzumahaus, A., Hoppe, L., Konrad, S., Musgen, P., Patz, H. W., Schafer, H. J., Schmitz, T., Volz-Thomas, A., Bachmann, K., Schlomski, S., Platt, U., Geyer, A., Alicke, B. and Moortgat, G. K.: Peroxy radicals during BERLIOZ at Pabstthum: Measurements, radical budgets and ozone production, J. Geophys. Res., 108, 8254, doi:10.1029/2001JD001014, 2003.

Moxim, W. J., Levy, H., and Kasibhatla, P. S.: Simulated global tropospheric PAN: Its transport and impact on $\mathrm{NO}_{\mathrm{x}}$, J. Geophys. Res., 101, 12621-12638, 1996.

Murphy, J. G., Day, D. A., Cleary, P. A., Wooldridge, P. J., and Cohen, R. C.: Observations of the diurnal and seasonal trends in nitrogen oxides in the western Sierra Nevada, Atmos. Chem. Phys., 6, 5321-5338, 2006, http://www.atmos-chem-phys.net/6/5321/2006/.

Murphy, J. G., Day, D. A., Cleary, P. A., Wooldridge, P. J., Millet, D. B., Goldstein, A. H., and Cohen, R. C.: The weekend effect within and downwind of Sacramento - Part 1: Observations of ozone, nitrogen oxides, and VOC reactivity, Atmos. Chem. Phys., 7, 5327-5339, 2007,

http://www.atmos-chem-phys.net/7/5327/2007/.

NASA, Chemical Kinetics and Photochemical Data for Use in Atmospheric Studies Evaluation Number 15, http://jpldataeval.jpl. nasa.gov/, last access: 16 March 2009, 2006.

Olszyna, K. J., Luria, M., and Meagher, J. F.: The correlation of temperature and rural ozone levels in southeastern USA, Atmos. Environ., 31, 3011-3022, 1997.

Orlando, J. J., Tyndall, G. S., and Paulson, S. E.: Mechanism of the $\mathrm{OH}$-initiated oxidation of methacrolein, Geophys. Res. Lett., 26, 2191-2194, 1999.

Orlando, J. J., Tyndall, G. S., Bertman, S. B., Chen, W. C., and Burkholder, J. B.: Rate coefficient for the reaction of $\mathrm{OH}$ with $\mathrm{CH}_{2}=\mathrm{C}\left(\mathrm{CH}_{3}\right) \mathrm{C}(\mathrm{O}) \mathrm{OONO}_{2}$ (MPAN), Atmos. Environ., 36, 1895-1900, 2002.

Parrish, D. D., Dunlea, E. J., Atlas, E. L., Schauffler, S., Donnelly, S., Stroud, V., Goldstein, A. H., Millet, D. B., McKay, M., Jaffe, D. A., Price, H. U., Hess, P. G., Flocke, F., and Roberts, J. M.: Changes in the photochemical environment of the temperate North Pacific troposphere in response to increased Asian emissions, J. Geophys. Res., 109, D23S18, doi:10.1029/2004GL004978, 2004.

Perez, I. M.: The Photochemical Evolution of the Sacramento Urban Plume: a Guide to Controlling Ozone now and in a Warmer Climate, Ph.D. thesis, University of California at Berkeley, Berkeley, CA, 2008.

Perez, I. M. and Cohen, R. C.: Nitrogen oxide chemistry in an urban plume, in preparation, 2009.

Roberts, J. M. and Bertman, S. B.: The Thermal-Decomposition of peroxyacetic nitric anhydride (PAN) and peroxymethacrylic nitric anhydride (MPAN), Int. J. Chem. Kinet., 24, 297-307, 1992.

Roberts, J. M., Parrish, D. D., Norton, R. B., Bertman, S. B., Holloway, J. S., Trainer, M., Fehsenfeld, F. C., Carroll, M. A., Albercook, G. M., Wang, T., and Forbes, G.: Episodic removal of $\mathrm{NO}_{\mathrm{y}}$ species from the marine boundary layer over the North Atlantic, J. Geophys. Res., 101, 28947-28960, 1996.

Roberts, J. M., Stroud, C. A., Jobson, B. T., Trainer, M., Hereid, D., Williams, E., Fehsenfeld, F., Brune, W., Martinez, M., and Harder, H.: Application of a sequential reaction model to PANs and aldehyde measurements in two urban areas, Geophys. Res. Lett., 28, 4583-4586, 2001.

Roberts, J. M., Flocke, F., Stroud, C. A., Hereid, D., Williams, E., Fehsenfeld, F., Brune, W., Martinez, M., and Harder, H.: Ground-based measurements of peroxycarboxylic nitric anhydrides (PANs) during the 1999 Southern Oxidants Study Nashville Intensive, J. Geophys. Res., 107, 4554, doi:10.1029/2001JD000947, 2002.

Roberts, J. M., Marchewka, M., Bertman, S. B., Goldan, P., Kuster, W., de Gouw, J., Warneke, C., Williams, E., Lerner, B., Murphy, P., Apel, E., and Fehsenfeld, F. C.: Analysis of the isoprene chemistry observed during the New England Air Quality Study (NEAQS) 2002 intensive experiment, J. Geophys. Res., 111, D23S12, doi:10.1029/2006JD007570, 2006.

Roberts, J. M., Marchewka, M., Bertman, S. B., Sommariva, R., Warneke, C., de Gouw, J., Kuster, W., Goldan, P., Williams, E., Lerner, B. M., Murphy, P., and Fehsenfeld, F. C.: Measurements of PANs during the New England air quality study 2002, J. Geophys. Res., 112, D20306, doi:10.1029/2007JD008667, 2007.

Romero, M. T. B., Blitz, M. A., Heard, D. E., Pilling, M. J., Price, B., Seakins, P. W., and Wang, L. M.: Photolysis of methylethyl, diethyl and methylvinyl ketones and their role in the atmospheric $\mathrm{HO}_{\mathrm{x}}$ budget, Faraday Discuss., 130, 73-88, 2005.

Schade, G. W., Goldstein, A. H., and Lamanna, M. S.: Are monoterpene emissions influenced by humidity?, Geophys. Res. Lett., 26, 2187-2190, 1999.

Schade, G. W., Goldstein, A. H., Gray, D. W., and Lerdau, M. T.: Canopy and leaf level 2-methyl-3-buten-2-ol fluxes from a ponderosa pine plantation, Atmos. Environ., 34, 3535-3544, 2000.

Schade, G. W. and Goldstein, A. H.: Fluxes of oxygenated volatile organic compounds from a ponderosa pine plantation, J. Geophys. Res., 106, 3111-3123, 2001.

Sillman, S. and Samson, F. J.: Impact of Temperature on Oxidant Photochemistry in Urban, Polluted Rural and Remote Environments, J. Geophys. Res., 100, 11497-11508, 1995.

Slusher, D. L., Huey, L. G., Tanner, D. J., Flocke, F. M., and Roberts, J. M.: A thermal dissociation-chemical ionization mass spectrometry (TD-CIMS) technique for the simultaneous measurement of peroxyacyl nitrates and dinitrogen pentoxide, J. Geophys. Res., 109, D19315, doi:10.1029/2004JD004670, 2004.

Smith, D. F., Kleindienst, T. E., and McIver, C. D.: Primary product distributions from the reaction of $\mathrm{OH}$ with $\mathrm{m}-, \mathrm{p}$-xylene, 1,2,4- and 1,3,5-trimethylbenzene, J. Atmos. Chem., 34, 339364, 1999.

Sparks, J. P., Roberts, J. M., and Monson, R. K.: The uptake of gaseous organic nitrogen by leaves: A significant global nitrogen transfer process, Geophys. Res. Lett., 30, 2189, 
doi:10.1029/2003GL018578, 2003.

Spaulding, R. S., Schade, G. W., Goldstein, A. H., and Charles, M. J.: Characterization of secondary atmospheric photooxidation products: Evidence for biogenic and anthropogenic sources, J. Geophys. Res., 108, 4247, doi:10.1029/2002JD002478, 2003.

Staffelbach, T. A., Orlando, J. J., Tyndall, G. S., and Calvert, J. G.: The UV-visible absorption-spectrum and photolysis quantum yields of methyl glyoxal, J. Geophys. Res., 100, 14189-14198, 1995.

Talukdar, R. K., Burkholder, J. B., Schmoltner, A. M., Roberts, J. M., Wilson, R. R., and Ravishankara, A. R.: Investigation of the loss processes for peroxyacetyl nitrate in the atmosphere: UV photolysis and reaction with OH, J. Geophys. Res., 100, 1416314173, 1995.

Tuazon, E. C., Macleod, H., Atkinson, R., and Carter, W. P. L.: Alpha-Dicarbonyl Yields from the $\mathrm{NO}_{\mathrm{x}}$-Air Photooxidations of a Series of Aromatic-Hydrocarbons in Air, Environ. Sci. Technol., 20, 383-387, 1986.

Tuazon, E. C. and Atkinson, R.: A product study of the gas-phase reaction of methyl vinyl ketone with the $\mathrm{OH}$ radical in the presence of $\mathrm{NO}_{\mathrm{X}}$, Int. J. Chem. Kinet., 21, 1141-1152, 1989.

Turnipseed, A. A., Huey, L. G., Nemitz, E., Stickel, R., Higgs, J., Tanner, D. J., Slusher, D. L., Sparks, J. P., Flocke, F., and Guenther, A.: Eddy covariance fluxes of peroxyacetyl nitrates (PANs) and $\mathrm{NO}_{\mathrm{y}}$ to a coniferous forest, J. Geophys. Res., 111, D09304, doi:10.1029/2005JD006631, 2006.

Villalta, P. W. and Howard, C. J.: Direct kinetics study of the $\mathrm{CH}_{3} \mathrm{C}(\mathrm{O}) \mathrm{O}_{2}+\mathrm{NO}$ reaction using chemical ionization mass spectrometry, J. Phys. Chem., 100, 13624-13628, 1996.
Villenave, E., Lesclaux, R., Seefeld, S., and Stockwell, W. R.: Kinetics and atmospheric implications of peroxy radical cross reactions involving the $\mathrm{CH}_{3} \mathrm{C}(\mathrm{O}) \mathrm{O}_{2}$ radical, J. Geophys. Res., 103, 25273-25285, 1998.

Williams, J., Roberts, J. M., Fehsenfeld, F. C., Bertman, S. B., Buhr, M. P., Goldan, P. D., Hubler, G., Kuster, W. C., Ryerson, T. B., Trainer, M., and Young, V.: Regional ozone from biogenic hydrocarbons deduced from airborne measurements of PAN, PPN, and MPAN, Geophys. Res. Lett., 24, 1099-1102, 1997.

Williams, J., Roberts, J. M., Bertman, S. B., Stroud, C. A., Fehsenfeld, F. C., Baumann, K., Buhr, M. P., Knapp, K., Murphy, P. C., Nowick, M., and Williams, E. J.: A method for the airborne measurement of PAN, PPN, and MPAN, J. Geophys. Res., 105, 28943-28960, 2000.

Wolfe, G. M., Thornton, J. A., Yatavelli, R. L. N., McKay, M., Goldstein, A. H., LaFranchi, B., Min, K.-E., and Cohen, R. C.: Eddy covariance fluxes of acyl peroxy nitrates (PAN, PPN and MPAN) above a Ponderosa pine forest, Atmos. Chem. Phys., 9, 615-634, 2009, http://www.atmos-chem-phys.net/9/615/2009/.

Wolfe, G. M., Thornton, J. A., McNeill, V. F., Jaffe, D. A., Reidmiller, D., Chand, D., Smith, J., Swartzendruber, P., Flocke, F., and Zheng, W.: Influence of trans-Pacific pollution transport on acyl peroxy nitrate abundances and speciation at Mount Bachelor Observatory during INTEX-B, Atmos. Chem. Phys., 7, 53095325, 2007, http://www.atmos-chem-phys.net/7/5309/2007/. 